\title{
21. Raif Necdet Kestelli'nin Hayat ve Mektuplar adlı eseri üzerine bir inceleme
}

\section{Salome BURDUL'í1}

\begin{abstract}
APA: Burduli, S. (2021). Raif Necdet Kestelli'nin Hayat ve Mektuplar adlı eseri üzerine bir inceleme. RumeliDE Dil ve Edebiyat Araştırmaları Dergisi, (22), 362-380. DOI: 10.29000/rumelide.895928.
\end{abstract}

\section{Öz}

Raif Necdet Milli Edebiyat Dönemi'nin önemli yazarlarından biridir. Realizm ve natüralizm etkisi altından kalan Kestelli, eserlerinde ele aldığı unsurlarla gerçek hayatın bir krokisini çizme ve vesikası olma etkisini yaratmaya çalışmıştır. Yaşadığı dönemde Türk milletinin her şeyini; zaaflarını, kudretini, asaletini, zaman zaman duyarsızlı̆̆ını, aşkını, dertlerini ve yaralarını, kısacası hayatlarını bir fotoğraf karesi gibi gözümüzün önüne koymayı ve yaşanan her şeyi eserlerinin her satırında gösterebilmeyi hedeflemiştir. Eser; dönemin evlilik kurumu, sağlık sistemi, ticari faaliyetleri, eğitim sistemi, kadının toplumdaki yeri, savaş ve savaşın getirdiği sıkıntılar gibi konuları içerir. Bu konular o dönemki Türk toplumunun aynası niteliğindedir. Bu amaçla yazdı̆̆ı eserlerden biri de Hayat ve Mektuplar'dır. Yazar bu eseri üç farklı kısım üzerinden, mektuplar hâlinde kaleme almıştır. Mektuplarda; Türk milletinin savaş sırasındaki ve savaştan sonraki etnik, kültürel, sosyal, siyasi ve eğitim yapısını anlatır. Eser; zihniyet, yapı ve dil başlıkları altında incelenmiştir. Eser 70 mektuptan oluşmakta olup mektuplarda toplumun her kesiminden insanların ağzından yazıldığı dönem anlatılmıştır. Bu eser Osmanlı Devleti’nin son, Türkiye Cumhuriyeti’nin ilk dönemleri hakkında resmi belge niteliği taşıyabilecek bulgular içerir.

Anahtar kelimeler: Mektup, Raif Necdet Kestelli, I. Dünya Savaşı, Anadolu insanı, Hayat ve Mektuplar

\section{The analysis of Raif Necdet Kestelli's work Lives and Letters}

\begin{abstract}
Raif Necdet is one of the important writers of the National Literature period. Under the influence of realism and naturalism, Kestelli has tried to create the effect of drawing and documenting a sketch of real life in his works. He described everything from weakness to power, dignity, rudeness, love, problems and wounds of the Turkish nation lived in that period. He aimed to picture everything as a photo frame in each line of his novels. His work includes topics such as the marriage of the period, the health system, commercial activities, the education system, the place of women in society, war and the war brought difficulties, which reflected the conditions of the Turkish society in that era. One of the works he wrote with this purpose is "Life and Letters". The author has written letters in three different parts. The letters described the ethnic, cultural, social, political and educational structure of the Turkish state during and after the war. This thesis aims to examine the novel from, structural, thematic and linguistic aspect. The work consists of 70 letters and describes the period, where the people of society was writting what they were talking. This research contains officias document and information about the end of the Ottoman Empire and the beginning of the Turkish Republik period.
\end{abstract}

YL Öğrencisi, Sakarya Üniversitesi, Sosyal Bilimler Enstitüsü, Türk Dili ve Edebiyatı ABD (Sakarya, Türkiye), sburduli@mfa.gov.ge, ORCID ID: oooo-0002-5738-758X [Araştırma makalesi, Makale kayit tarihi: 07.12.2020-kabul tarihi: 20.03.2021; DOI: 10.29000/rumelide.895928]

Adres

RumeliDE Dil ve Edebiyat Araşttrmaları Dergisi Osmanağa Mahallesi, Mürver Çiçeği Sokak, No:14/8 Kadıköy - ÍSTANBUL / TÜRKIYE 34714 e-posta: editor@rumelide.com tel: +90 $5057958124,+902167730616$

\section{Address}

RumeliDE Journal of Language and Literature Studies

Osmanağa Mahallesi, Mürver Çiçeği Sokak, No:14/8

Kadıköy - ISTANBUL / TURKEY 34714

e-mail: editor@rumelide.com,

phone: +90 5057958124 , +90 2167730616 
Keywords: Letter, Raif Necdet Kestelli, World War I, Anatolian people, Life and Lett

\section{Giriş}

Bir iletişim aracı olarak mektubun tarihi, insanlık tarihi ile paralel yürümüştür. Türk Dil Kurumu, mektubu "Bir şey haber vermek, sormak, istemek veya duyguları bildirmek için birine çoğunlukla posta yoluyla gönderilen, zarfa konulmuş yazılı kâğıt, name” olarak tanımlarken (Türkçe Sözlük, 2011, s. 1647) şair, yazar ve edebiyat tarihçisi Seyit Kemâl Karaalioğlu "Birbirinden uzaktaki insanların, anlaşmak ve haberleşmek amacıyla yazdıkları, duyguları, dilekleri, düşünceleri tek kelimeyle maksadı bildirmek gayesiyle şahısların birbirlerine gönderdikleri yazıdır” biçiminde tanımlar (1982, s. 187). Yukarıda da ifade edildiği gibi mektup; başka birisiyle haberleşmek, ona bir maksadı bildirmek veya ayrı düşmüş kişilerin duygu, düşünce ve isteklerini birbirlerine taşıyı anlaşmalarını sağlamak amacıyla kullandıkları bir iletişim aracıdır. Bu araç, konu sınırlaması olmaksızın bütün hayatı içine alır. Aynı zamanda yazan kişinin iç dünyasını, dünyaya ve hayata bakış açısını, kişisel gelişimini, yaşadığı devri, toplumsal ve siyasi yapısını da yansıtır.

Mektup türleri hakkında çeşitli yaklaşımlar bulunmaktadır. Bazıları mektupları resmî ve özel mektup olmak üzere iki kısma ayırırken; Seyit Kemâl Karaalioğlu, iş mektupları ve özel mektuplar şeklinde ayırmaktadır (1982, s. 187). Bu farklılıklara rağmen mektuplar; özel, iş, resmî, açlk ve edebî olmak üzere sinıflandırılmaktadır.

Mektup türlerinin kısaca tanımı şu şekildedir:

Resmî mektuplar; devlet dairelerinin ve tüzel kişiliğe sahip kuruluşların birbirlerine yazdıkları resmî yazılarla; bunların, vatandaşların başvurularına verdikleri yazılı yanıtlardır.

Açık mektuplar; bir fikri, görüşü açıklamak, bir tezi savunmak için devlet erkânına ya da halka hitaben, bir kişi ya da kuruluş tarafından yazılan, gazeteler ya da dergiler aracılığı ile yayımlanan mektuplardır.

Edebî mektup; edebiyat alanında ünlenmiş kişilerin, akraba ve ahbaplarına yazdıkları mektuplardır. $\mathrm{Bu}$ mektuplarda yazar; çeşitli sanat dallarını ve cemiyeti ilgilendiren konuları ele aldığından edebî açıdan önem taşıyan mektuplardır. Sonraki nesillere aktaracakları bu kültürel miras ile devirler içinde kuşakların kaynaşmasını ve pekişmesini sağlayan edebî mektuplar; zaman geçtikçe, tarihsel bir özellik kazanarak birer belge durumuna geçerler (Kaplan, 1999, s. 3).

İş mektupları; özel kişi-iş kurumları ve iş kurumları-iş kurumları arasında yazılan iş ile alakalı mektuplara denir. Bu mektuplarda içeriği fark etmeksizin bir iş ya da hizmet söz konusudur.

Özel mektuplar; aile, eş, dost, akraba, yakın arkadaş ve meslektaşlar arasında yazılan mektup çeşididir. Bu tür mektuplarda doğal ve içten anlatım daha çok öne çlkar. Özel mektuplar; giriş, gelişme ve sonuç bölümünden oluşur. Mektubun yazılış amacı giriş bölümünde belirtilir ve mektup selamlama ile başlar. Gelişme bölümünde mektubun ana fikrine yer verilir.

Mektubun sonuç bölümünde ise sevgi, saygı ve temenniler yer alır. Mektup kağıdının sağ alt köşesinde mektubu yazanın adı ve imzası, mektup kâğıdının sağ üst köşesinde de yer ve tarih yazılı olmalıdır.

Orhan Okay mektuba "Edebî Türler Arasında Bazı Alt Kategoriler" (Okay, 2010, s. 216) başlığı altında yer verir. "İnsanların özel hayatını veya sadece yazdığı kişilerle ilişkilerini ilgilendirdiği için doğrudan

\footnotetext{
\begin{tabular}{r|l} 
Adres & Address \\
RumeliDE Dil ve Edebiyat Araşttrmalar Dergisi & RumeliDE Journal of Language and Literature Studies
\end{tabular} Osmanağa Mahallesi, Mürver Çiçeği Sokak, No:14/8 Osmanağa Mahallesi, Mürver Çiçeği Sokak, No:14/8 Kadıköy - İSTANBUL / TÜRKIYE 34714 Kadıköy - ISTANBUL / TURKEY 34714 e-posta: editor@rumelide.com e-mail: editor@rumelide.com, tel: +90 505 7958124, +90 2167730616 phone: +90 505 7958124, +90 2167730616
} 
doğruya bir edebî metin sayılma(yacağını)" söyler. Dil, üslup, kompozisyon ve belli bir oranda kurmaca özellikleri taşıdığında edebî bir tür olarak kabul edilebileceğini belirtir. "Ancak, mektup şeklinde yazılan, bir çeşit deneme/eleştiri yazısı sayılabilecek metinler ile manzum mektuplar, klasik mesnevilerdeki mektuplar ve bazı romanlardaki mektup metinleri, hatta tamamen mektuplardan ibaret romanlar hakkında bir edebî türden veya tür içinde edebî anlatım tekniğinden bahsedilebilir." (Okay, 2010, s. 225) Orhan Okay, "özel mektupların bir edebî tür olmasının dışında netice itibariyle birer belge değeri taşımalarının daha ön planda geldiği(ni)” belirtir (Okay, 2010, s. 226).

Mektubun tarihçesi çok eski çağlara dayanmaktadır. Günümüzde bulunan en eski mektuplardan biri; Sümer dilinde, çivi yazısıyla yazılmış bir kil tablettir ve yaklaşık M.Ö. 2100-2016 arasında bir zaman aralığında yazılmışırı. Eski Mezopotamya ve Anadolu uygarlıklarını yaratan ya da geliştiren Sümerler, Asurlular, Hititler gibi birçok medeniyetten günümüze, dönemin siyasi yapısı ile ilgili ya da kişisel pek çok mektup kalmıştır. Kültepe, Boğazköy, Alacahöyük, Maşat, Hatay ve son olarak da ÇorumOrtaköy'de yapılan kazılar yardımıyla arşivlerdeki binlerce mektup gün ışığına çıkarılmıştır. Çivi yazısı ile yazılmış bu tabletten mektuplar o dönemdeki medeniyetlerle alakalı konularda edinmekte olduğumuz bilgilerin en önemli kaynağını oluşturmaktadır (Özaktürk, 200o, s. 143).

Mektup, yazının tarihi kadar eskidir ancak firavunların diplomatik özellik taşıyan mektup örnekleri bizleri; Mısır'da bulunan meşhur "Çömelmiş Kâtip" heykeli kalıntılarından daha da eskiye götürülebileceğinin kanıtıdır (Eroğlu, 2000, s. 3).

Antik Yunan'da mektup, klasik edebiyatta olduğu gibi halk yaşamında önemli bir rol almıştır. Bu dönemde Platon, Demosthenes ve Sokrates'in mektupları bugün dahi okunmaktadır. Roma'daki askerî seferler, sömürgeciliğin gelişmesi, büyük yolların Doğu'yla birleşmesi sonucunda mektup ile iletişim kurmada büyük bir ilerleme kaydedilmiştir. Latin edebiyatının ilk büyük ustası ise Cicero'dur. Cicero'nun mektupları birer tarih belgesinden ibaret olsa da yaşadığı dönemin kültürel ve siyasi yapısını yansıtması açısından oldukça önemlidir (Eroğlu, 2000, s. 3).

Tarihsel süreç içerisinde, 14. yüzylda mektuplar, kâğıdın bulunmasıyla birlikte yaygın olarak kullanılmaya başlanmışırı. Okuryazarlık oranının o yıllarda düşük olması nedeniyle mektupları, daha çok çarşı, pazar gibi yerlerde bulunan kâtipler kaleme almışlardır (Kaplan, 1999, s. 4).

Orta Çă̆ mektup türü itibariyle tam bir boşluktan ibarettir ve mektuplar ancak Hümanizmanın etkisiyle yeniden önem kazanacaktır. Hümanizmin etkisindeki mektuplar, konuları itibariyle de çeşitlilik kazanmıştır. Dante'nin sınırlı sayıdaki sürgün mektupları, Petrarca, Machiavelli, Aretine, Tasso ve Ariosto'nun fikir ağırlıklı mektupları, Almanya'da Luther'in mektupları bu hızlı çıkışa birer örnektir. Fakat mektup edebiyatının tam anlamıla oturabilmesi Avrupa'da 17. yüzyılda gerçekleşmiştir. Bu yüzyıldan itibaren dünya edebiyatına mal olmuş, zevkle okunabilecek mektuplar yazılmaya başlanmıştır (Eroğlu, 2000, s. 3).

Fransız edebiyatındaki en ünlü mektup yazarı Madame de Sévigné’dir. Evlenip yanından ayrılan kızına yani Françoise'ya yazdığı bu mektuplarda dönemin Paris'ini ve 14. Louis sarayını, entrikalarını, aşk hikâyelerini günümüze taşır. Sévigné’nin 30 yıl boyunca yazdığı tahmini 1220 mektup, kızına olan özlemini anlatır. Bu mektuplar günümüzde o dönemi anlatan benzersiz birer tarihî belgedir (Karataş, 2012, s. 2176). Voltaire saylları yirmi bini geçkin mektuplarında Fransız tarihî ve sosyal yaşamına dair önemli ayrıntılara yer vermiştir. Flaubert, Stendhal, Proust, Diderot ve Mallarmée Fransız

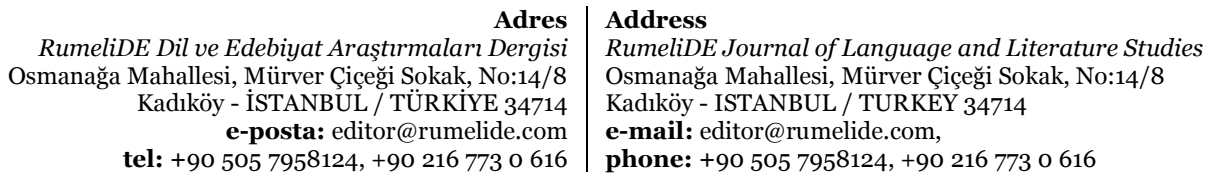


edebiyatında bu türün en eşsiz örneklerini veren kişileridir. Balzac’ın İki Yeni Gelinin Hattraları romanı ise mektup romanın en gelişmiş örneklerindendir.

Alman edebiyatında mektup türü 18. yüzyılda zirveye ulaşır. Goethe'nin Genç Werther’in Ačları adlı romanı içerdiği mektuplar bakımından dünya edebiyatında özel bir yere sahiptir. Schiller de Alman edebiyatının önemli mektup yazarları arasındadır (Karataş, 2012, s. 2176).

İngiliz edebiyatında Jonathan Swift'in; çocuk edebiyatı açısından da önemli olan çalışması Journal to Stella ile Lady Mary Wortley Montagu'nun The Turkish Embassy Letters adlı eserleri dikkate alınmaya değer eserlerdir. Ayrıca Emily Charlotte ve Anne Bronté kardeşlerin mektuplaşmaları kadın edebiyatı açısından ayrı bir önem teşkil etmektedir (Karataş, 2012, s. 2176).

Mektup diğer bölgelerde olduğu gibi Amerika'da da toplumsal ve siyasal konuların çözümlenmesinde kullanılmıştır. Ancak daha sonra mektup bireysel bir ivme kazanmıştır. Wolda Emerson, Edgar Allan Poe, Mark Twain, Henry James, Ezra Pound Amerikan edebiyatının en önemli mektup yazarları arasındadır (Karataş, 2012, s. 2176).

Rus edebiyatında mektup türünün ilk izlerine 16. yüzyılda rastlanır. Bu türün Rus edebiyatındaki en meşhur örnekleri Nikolay Karamzin'in Rus Gezginin Mektupları, Puşkin'in Mektuplarla Roman ve Dostoyevski'nin İnsancıklar adlı eserleridir. Bu alanda Gorki ve Lermantof'un mektuplarını hatırlayabiliriz. Tolstoy'un mektupları ise edebî, felsefî, toplumsal içerikler barındırması ve döneme dair içli tenkitler bulundurması bakımından uluslararası bir önem taşımaktadır (Diakova \& Rijova, 2013, S. 15).

Türk edebiyatında önemli mektup örneklerine Divan edebiyatı içerisinde rastlanmakta ve Arap mektup geleneğinin örnek alındığı görülmektedir. Türk edebiyatında münşeât isimli kitaplar ilk mektup örneklerinin görüldüğü kaynaklardır. Tanzimat'a kadar mektuplar inşa adı verilen nesirlerin bir parçası olarak görülmüş, önemli kişilerin mektuplaşmaları münşeât isimli eserlerde toplanmıştır. İnşa bir sanat kolu değil bir bilim dalı olarak kabul görmüştür. Bu anlayış çerçevesinde mektup yazmak, hem tecrübe hem de yetenek gerektiren sanatsal bir faaliyet olarak görülmüştür. İlk başlarda amaç sadece yazmak iken bunun yerini İran üslubunun etkisiyle gösterişli anlatımlar almıştır. Bu yüzden mektup yazmanın asıl gayesi ortadan kaybolmaya başlamıştır. Yani mektup yazmak bir amaç iken güzel sözler söylemek için bir araç hâline gelmiştir.

Yukarıda belirtilen anlayışın aksine bu genel kalıpların dışında yazılmış nadir mektup örneklerine rastlamak da mümkündür. Bunların en meşhuru Fuzuli'nin Şikâyet-nâmesi'dir. Bu mektup bulunduğu döneme göre sade bir dile sahiptir.

Bu dönemde görülen bir başka mektup biçimi ise yetenek göstermek için şekilsel deneylerin yapıldığı mektuplardır. "Noktasız harflerle belli bir konunun, tersane, dil bilgisi, müzik terimleri ile kuş, meyve, çiçek adlarıyla; müstezatlı ifadelerle baştan sonra aynı harfin ayağına bağlı secilerle ve benzeri hüner göstermek için yazılmış mektup sayısı hiç de az değildir” (Gökyay, 1974, s. 20).

Mektup birden fazla isimle anılmıştır. Mektubun adı, yazan kişiye ve yazılan kişiye göre farklılık gösterebilir. Divan edebiyatı geleneğinde bir mektupta bulunması gereken temel bölümler şunlardır: hû, beduh, elkab, dibace, asıl konu, dua, selâm ve imza. Halk geleneği içerisinde ise asker ve aşk mektuplarının önemli bir yeri vardır (Karataş, 2012, s. 2177).

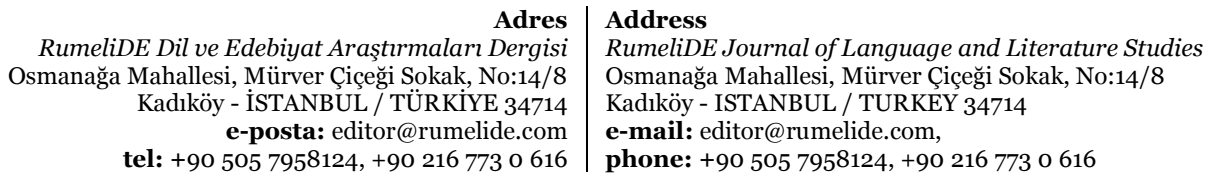


Tanzimat döneminde Şinasi'nin öncülüğünü yaptığı yeni nesir anlayışı mektup türünde de kendini gösterir. Süslü ve şatafatlı anlatımdan uzaklaşlarak Tanzimat döneminden Cumhuriyet dönemine kadar gösterişli anlatım gayesi güdülmeyen yalın ve saf bir dil ile mektuplar yazılır.

Tanzimat'tan sonra mektuplar tek bir kitap içerisinde toplanmaya başlamış bu da yeni bir edebiyat anlayışının oturmasına büyük katkı sağlamıştır. Akif Paşa'nın mektupları, Münşeât-ı Elhac Akif Efendi (1843) ve Muharrerât-ı Husûsiye-i Akif Paşa (1884) adlı iki eserde toplanmıştır. İlki daha çok Mabeyn'e gönderdiği resmi yazılardan oluşur. İkincisinde ise sürgüne gönderildiğinde çektiği sıkıntılardan bahsedilir. Bu dönemde en çok dikkat çeken mektuplardan biri de Şinasi'nin Paris'ten annesine yazdığı mektuplardır. Dönemin en fazla mektup yazan isimlerinden biri Namık Kemal diğeri ise Abdülhak Hamit Tarhan'dır (Donbay, 2011, s. 87).

II. Meşrutiyet'ten sonra Safveti Ziya'nın Hanım Mektupları (1913) ve Ahmet Rasim'in İlaveli Hazine-i Mekâtib yahûd Mükemmel Münşeat (1331/1915) gibi farklı ve mühim çalışmaları yayımlandığı gibi, Millî Edebiyat döneminden Cumhuriyet'e geçerken mektup türüne dört ayrı eseriyle hizmet eden Raif Necdet [Kestelli] gibi yazarların da yetiştiği görülür: Fikri ve Ahlaki Mektuplar (1328), Hayat ve Mektuplar I-II (1925), Yeni Mektup Numuneleri (1925) ve Talebe Mektuplarl (1927). Halide Nusret'in [Zorlutuna] Hanım Mektupları (1342-1923) da yine Cumhuriyet'in ilk yllarında yayımlanır (Donbay, 2011, s. 87).

Servet-i Fünûn'dan Fecr-i Âti'ye, Millî Edebiyat'tan Cumhuriyet devrine, Türk edebiyatının her döneminde mektuplaşmak her şeyden önce bir zevk ve alışkanlık olarak edebiyatçılar arasında yaygınlaşmıştır. Bir mektupta mektup yazan yazarın ve yazıldığı dönemin izleri fazlasıyla bulunur. Bu da edebiyat tarihçilerinin, eleştirmenlerin hatta ve hatta okuyucuların mektuplara duydukları ilgiyi artırir.

Türk edebiyatında ilk defa mektupla roman yazmayı Hüseyin Rahmi Gürpınar Mutallaka isimli eserinde denemiştir (Kaplan, 1999, s. 9). Mektubu, bir roman içerisinde anlatım tekniği olarak kullanan ilk yazar ise Felsefe-i Zenan romanı ile Ahmet Mithat Efendi'dir. İlk Türk romanı olan Taaşşuk-ı Talat ve Fitnat ile Cezmi'de de eserlerin kurgusunu desteklemek için mektup türünden faydalanıldığı görülmüştür (Karataş, 2012, s. 2178).

Hüseyin Rahmi Gürpınar'ın Sevda Peşinde'nin ikinci bölümü; Ömer Seyfettin'in Bahar ve Kelebekler, Tarih Ezeli Bir Tekerrürdür, Aşk ve Ayak Parmakları, Sivrisinek, Memlekete Mektup Hikâyeleri; Halide Edip Adıvar'ın Handan'ı; Yakup Kadri Karaosmanoğlu'nun Kadınlı ve Kadınlarmız, Bir Serencam, Milli Savaş Hikâyeleri; Reşat Nuri Güntekin’in "Sönmüş Yıldızlar”, "Bir Damla Gözyaşı”, "Yalan”, "Bir Hayal Kırıklı̆̆ı" adlı hikâyeleri mektup tarzındadır. Bunlardan başka Halit Ziya, Mehmet Rauf, Ahmet Hikmet ve Sait Faik’in bazı hikâyeleri de mektup şeklinde yazılmışlardır (Kaplan, 1999, s. 9).

Yukarıda da bahsedildiği gibi Raif Necdet mektup türünde Türk Edebiyatı için değerli eserler bırakmıştır. Bunlardan bir tanesi de bu makalenin konusu olan Hayat ve Mektuplar adlı eserdir.

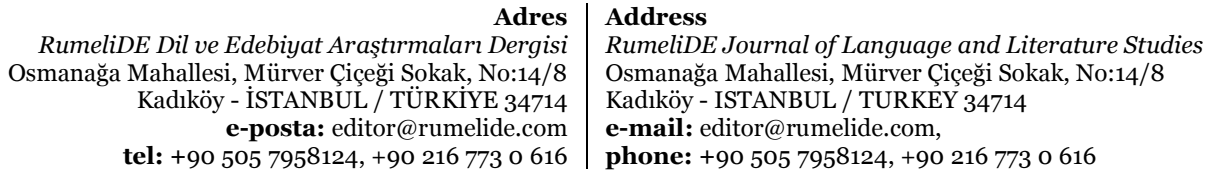

tel: +90 505 7958124, +90 2167730616 


\section{Raif Necdet ve hayat ve mektuplar}

\section{Raif Necdet Kestelli}

Raif Necdet Kestelli 1881 yılında İzmir'de dünyaya gelmiştir. İlköğrenimini İzmir'de, ortaöğrenimini İstanbul'da Kuleli Askerî Rüştiye ve İdadisi'nde, yükseköğrenimini ise Mekteb-i Harbiye'de başarıyla tamamladıktan sonra subay olarak orduya katılmıştır. 1909 yılının Eylül ayından itibaren Resimli Kitap mecmuasının her sayısında mensur şiir, edebî musahabe, edebî tenkitler ve öyküler yayımlamaya başlar. 1914 yılının Mart ayına kadar süregelen bu faaliyetiyle II. Meşrutiyet döneminin en önemli eleştiri yazarı olarak tanınır. Diğer yandan Kuleli Askerî Lisesi’nde edebiyat hocalığına devam eden Necdet, bu yllarda eserlerini kitap hâline getirir. Tolstoy'un Bir İzdivacın Romanı'nı 1910 yllında Fransizcadan, Anna Karenina adlı eserini ise M. Sadık ile birlikte 1912'de 4 cilt olarak tercüme ederek yayımlar. 1910'da yayımladığı Hisler ve Fikirler adlı eserinde 1901-1910 yılları arasında Serveti Fünûn, Musavver Muhit, Resimli Kitap gibi mecmualarda yayımladığı felsefî, edebî yazılarını ve hikâyelerini toplamıştır. 1325/1909 yılında Resimli İstanbul gazetesinde yayımladığı mektuplarını Fỉkrî ve Ahlâkî Mektuplar adıyla 1912 yllında bastırır. 1913 yılında gençliğe seslendiği Üfûl eserini yayımlar. Millî, destansı özelliklere sahip olan eserde Raif Necdet'in gözlemleri ve tespitleri de oldukça ilgi çekicidir. 1919'da M. Rauf'la beraber yazdıkları Tiraje isimli oyunu yayımlarlar. 1909-1922 yılları arasındaki eleştirini 1922 yılında Hayât-ı Edebiyye adıyla yayımlar. 1924'te Ziyâ ve Sevdâ isimli eseri yayımlar. 1925'te iki ciltlik Hayât ve Mektuplar isimli eser basılır. 1927'de Yeni Resimli Türkçe Kamus 840 sayfa olarak basılır. Aynı yıl Yeni Mektup Numuneleri'ni ve Talebe Mektupları'nı bastırır. 1932'de eski yazılarından seçtiği eserleri ve yeni makalelerini topladığı Yirminci Asır'ı yayımlar. 1933'te Semavî İhtirâs romanı yayınlanır. 1935'te 3 ciltlik Süzme Sözler isimli eserinde vecizelerini yayımlamıştır. Son eseri ise 1936 'da basılan ve kronolojik bir eser olan Yaşayan Mısralar adlı şiir antolojisidir (Ylldırım, 1983/84, s. 4).

Raif Necdet Kestelli, sadece asker ve edebiyatçı kişiliğiyle değil, aynı zamanda dönemin aydın kavramına uygun bir kişilik olarak da tanınır. Dilcidir, çevirmendir; kuramcı ve eleştirmendir; tiyatrocu ve aynı zamanda hararetli bir siyasetçidir. Bazı mevzularda muhalif davranmasına karşın edebî anlayış açısından Millî Edebiyat akımına yakın bir yazardır. Bu yakınlık vatan, millet, hürriyet, adalet; millî dil, tarih ve edebiyatta öze dönüş; tarihsel olaylara, millî ve manevî değerlere yaklaşım konularına göre değerlendirilebilir (Erol, 2017, s. 630).

Millî Edebiyat döneminde edebiyat nazariyesi çalışmalarına dahil olan Raif Necdet Kestelli, 1908-1913 yılları arasında 51 sayı yayımlanan Resimli Kitap mecmuasında edebiyat musahabelerine daimî katılım gösterir ve dönemin edebiyat mevzularına eleştirel yaklaşımlarda bulunur. "Sanat toplum içindir.” görüşünü kabul eden yazar, Fecr-i Âtî topluluğunun edebiyat ve sanat anlayışına eleştirilerde bulunmuştur. Millî Edebiyat hareketinin dil, edebiyat, sanat ve kültür dallarında "öze dönüş" anlayışını sahiplenir lakin edebiyatta millî ideolojiyle beraber sanat ve estetiğin de korunması gerektiğini savunur. Hayât-ı Edebiyye adlı eseri, onun edebiyat musahabelerinde yer alan bu yönlü eleştiri yazılarını barındırır. Yakup Kadri Karaosmanoğlu, Mithat Cemal Kuntay ve Mehmet Fuat Köprülü ile giriştiği edebiyat münakaşalarında ortaya koyduğu yenilikçi fikirlerle II. Meşrutiyet döneminin eleştiri tarihine adını yazdıran mühim münekkitler arasındaki yerini alır (Erol, 2017, s. $630)$.

Dönemin sanat, edebiyat tartışmalarına; siyasi, sosyal ve kültürel meselelerine eleştirel yaklaşan Raif Necdet, hayatı ve çevresini iyi tanımış, algıları yüksek biridir. O, farklı farklı yazılarında ortaya attığı

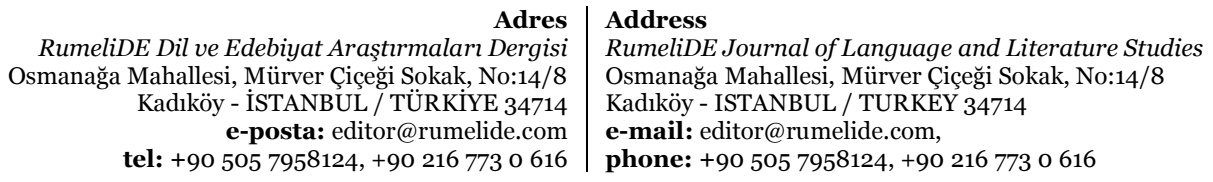


düşünceleriyle, dil ve edebiyatın muhtelif mevzularıyla ilgili eleştirileriyle ve kimi zaman gösterdiği alay edercesine yaklaşımlarıyla dikkatleri her zaman üzerinde toplamış bir isimdir. Yazarın genel olarak edebiyat çalışmalarında gösterdiği başarıda şahsî mizacı ve bilgi birikiminin belirleyici faktörler olduğunu söylemek mümkündür (Erol, 2017, s. 631).

İncelenecek olan Hayat ve Mektuplar adlı eserde realizme uyarak; genel olarak bilgisizliğe, imla yanlışlarına, Birinci Dünya Savaşı’na, eğitimin ve çalışmanın önemine, dönemin cehaletine ve sosyal yaralara halkın her tabakasından insanların ağzından mektuplar yazarak yer vermiştir. Ramazan Aydın, Râîf Necdet ve Yeni Mektûb Numûneleri incelemesinde eserden şöyle bahseder:

\begin{abstract}
"Hayat ve Mektuplar eseri bir bakıma dönemin bütün hayatını anlatması yönüyle tarihe, ekonomiye, siyasete, kültüre dair birçok meseleye el atması, bir romana girebilecek derecede ayrıntılı olması nedeniyle geçmişi ve geleceği aydınlatan gerçekçi bir eser olmuştur.” (2015, s. 29)
\end{abstract}

Eser üç kısım ve toplamda yetmiş mektuptan oluşur. Mektuplar herhangi bir kronolojik sıraya yahut birbirleriyle herhangi bir bağlantıya sahip değildir. Yazarın da belirttiği gibi mektuplar karışık olarak yazılmıştır ve belli bir kronolojik sıralama yahut belli bir olay yapısına sahip değildir. Yalnızca kitabın bölümlerini oluşturan üç kısım bir iki ve üç olarak sıralandığında birden üçe doğru mektubu yazan insanların eğitim seviyelerinin artış gösterdiği vurgusu yapılmıştır. Ayrıca eserde keskin bir şekilde belirtilmiş kişiler de yer almaz. Ancak yazarın dilinden eserdeki kişileri şöyle sıralayabiliriz: Birinci kzsım “köylünün, askerin, halkın, ruhen temiz fakat fikren aşağı tabakada bulunan kitle-
i nâsın mektuplarıdır...” (Kestelli, 1925, s. 9)

İkinci kusım "yarım yamalak tahsil görmüş tabakanın derece derece yazılmış mektuplarından müteşekkildir." (Kestelli, 1925, s. 11)

Üçüncü kssım "yüksek tahsil görmüş münevver ve güzîde tabakanın mektuplartndan terekküb etmiştir.” (Kestelli, 1925, s. 12)

Eser zaman bakımından geniş bir çerçeveye sahiptir. Belirli bir kronolojik sıralama yoktur lakin mektuplar incelendiğinde olayların anlatımı Balkan Savaşı'nın sonrası - I. Dünya Savaşı'nın başı ile başlayıp Cumhuriyet’in kurulması ile biter. Bu süreçte yaşanılanlar gerçek zaman ile anlatılmış olup birer tarihî belge niteliği taşıması hedefi konulmuştur. Mektuplarda yer alan mekânların tamamı somut, insanların içerisinde var olduğu ve anlatılan olayların fiili olarak hayata geçtiği yerlerdir. Eserdeki mekânlar İstanbul ve Anadolu'dur. Ancak mektuplarda anlatılanlar; İstanbul'un ve Anadolu'nun fiziki yapısı yahut tasvirleri değil, mekânlar içinde yaşanan olayların tasvirleri ve bu mekânlar içerisinde bulunan insanların psikolojik yapılarıdır. Eserin ilk kısmı içerisinde mekânlara detaylı olarak yer verilmese de üçüncü kısımda mektup ("Bir Seyahatin Hikâyesi”) yazarlarından biri içinde bulunulan İstanbul'u ve İzmir’i uzun uzadıya anlatmış bu şehirlerin aslında hayalindeki şehirler olabilmesi için hangi sokağa ne yapılması gerektiğine dair detaylar vermiş ancak bu detaylar bize mekânları tanıtmaktan çok o mekânlarda yaşayan insanların ahlak kurallarını ve hükûmetin sorumlu olduğu mekânlara ilgisizliğini anlatır.

\title{
2. Hayat ve Mektuplar
}

Raif Necdet eserinin başında “Birkaç Söz” başlıklı giriş kısmında böyle bir eseri yazma amacını açıklar. "Yazacağım bir eserle, bir romanla ictimâî̀ hayatımızın ruha heyecan ve ziyâ verebilecek bir fotoğrafını almak öteden beri en büyük, en muazzez bir emelimdi." (1925, s. 5) diyerek Emile Zola’nın "Edebiyat, hayât-ı ictimâ‘iyyenin ifadesidir.” (1925, s. 5) sözünü hatırlatır. Bu sözün kendisini son derece etkilediğini fakat böyle bir amaca ulaşmak için kendisinde yeter derecede kudret göremediğini belirtir.

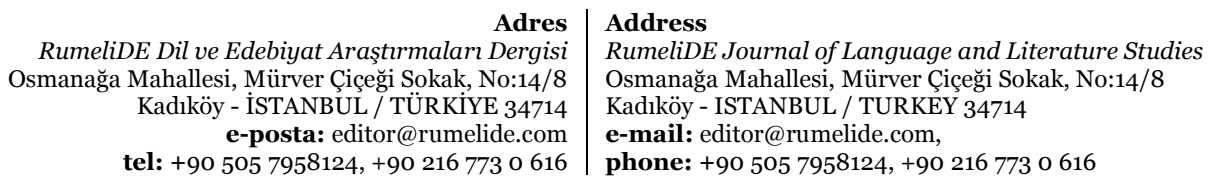


Uzun bir bekleme döneminden sonra yazarda yeni bir fikir belirir. "Bu derece muazzam ve nevvâr bir eser, bir roman yazamıyor, hayat ve hakikati sanatkârane tasvir ve tersim edemiyorsam acaba muhtelif hatlarla kabataslak ictimâî̀ ve ruhi bir kroki de mi yapamam?” (1925, s. 5) düşüncesinden sonra kendi içinde bir çözüm yolu bulur. Hatlarını ve unsurlarını mektupların oluşturacağı edebî bir kroki çizecektir. "Bir milletin filan zamanda veya devrede yazdı̆̆ ruhunu, hayatını, hatta biraz da -cüzîiden külle intikal suretiyle- beşeriyyet-i umûmiyyenin temâyülât ve ihtirâsâtını gösterir emin ve metin bir vesika az bulunur." (1925, s. 7) diyerek çeşitli tabakalara mensup insanların belirli bir dönemde yazdıkları mektupları zihninden geçirir. Türk hayatının ve Türk ruhunun belirli bir döneminin krokisini mektuplar aracılığıyla çizmek istediğini belirtir. "Bu suretle şu naçiz eser, tarîh-i edebiyyâtın şimdiye kadar gösterdiği envâ'-1 edebiyyeden hiçbirine ithali mümkün görünmeyen şu müstakil mektuplardan müteşekkil roman vücuda geldi.” (1925, s. 7) der .

"Filhakika düşünülecek olursa hayat ile, muhit ve zaman ile mektuplar arasındaki münasebet ve rabıtanın pek derin, ezelî ve samimi olduğu teslim edilir. O hâlde bir milleti ve bir devreyi hakiki simasıyla yaşatacak vesâ'it ve vesâ'ik arasında mektupların müstesna bir kıymet ve ehemmiyete malik olduğuna kanaat getirmek lazım gelir." (1925, s. 7) diyerek bu kanaatin verdiği şevk ile uzun süre çalışarak nevi şahsına münhasır böyle bir eseri yazdığını belirtir. Eseri yazarken "hakikat" ve "sanat" gibi iki önemli unsuru göz önünde bulundurur. Raif Necdet yazının devamında "Bir nev küçük hikâye telâkki edilebilen" (1925, s. 9) mektupları üç kısma ayırdığını söyler.

Birinci kısım; köylünün, askerin, halkın, yani yazarın deyimiyle "ruhen temiz fakat fikren aşağı tabakadaki” (1925, s. 9) insanların ağzından, ikinci kısım "yarım yamalak tahsil görmüş tabakadaki” (1925, s. 11) insanların ağzından, üçüncü kısım ise "yüksek tahsil görmüş aydın ve seçkin tabakadaki" (1925, s. 12) insanların ağzından yazılmıştır. Mektuplarda bahsedilen olayların kimisi; tamamen yazarın hayal gücü ile oluşturulmuş, kimisi ise gerçek olayları benzetme ile anlatmaya yönelik yazılmıştır. Yazar "Sanat sanat içindir." anlayışının daima karşısında durmuştur. Bu sebepten eserini toplum için yazmış, eseriyle bir devrin cllız, kırık dökük bir çeşit tarihi, hikâyesi olabilmeyi hedeflemiştir. Emellerinden birisi de faziletin kudretini, iyiliği ve güzelliği bir gelin taravetiyle ortaya çıkarmak, idealini anlatabilmektir. Unutulmamalıdır ki dünya üzerinde yapılan bütün savaşlarda kazanan taraf daima ilim, irfan, sanat ve sağlam kafa, kaybeden taraf ise cehalet ve körü körüne bağllık olacaktır.

Birinci Kısım'daki mektupların birçoğu savaş döneminde askere çağırılmış olup köyünden, evinden, çocuğundan, eşinden dostundan ve akrabalarından ayrı kalan askerlerin yakınlarına yazmış olduklarıdır. Bunun yanı sıra Anadolu'nun köylerinde bulunan annelerden şehir dışına çıkmış olan yahut başka yerlerde memuriyeti bulunan evlatlarına, sefalet içinde kalan yeğenlerinden borç istemek için amcalarına, kadınlardan İstanbul'daki kocalarına yazdıkları mektuplar gibi parçalar da yer alır.

Savaş esnasında halkın çektiği yoksulluktan, hayat şartlarının zorluğundan, her şeyin fiyatının artmasının yanı sıra parayla dahi zor ürün bulunduğundan, insanların açlıktan ve hastalıktan öldüğünden, bazı zamanlar yiyecek bulunamamasından dolayı insanların hayvanlar gibi ot yediğinden, yakacakları tükendiği için soğuktan titreyip açlıktan inlediklerinden, yattıkları yerde hayvanların dahi yatmayacağından, hasta olanlara bir kâse çorba dahi pişiremediklerinden, hayvanların bile insanlardan daha iyi beslenip karınlarını doyurduklarından bahsediliyor:

“Çoluk çocuk aç kaldık.. Otları pişirip yiyoruz.. Hiç ağaç kalmadı; ateş bulamıyoruz. Daha sıcak olur diye ahırda yatıyoruz.. Daha doğrusunu istersen lâgar hayvanlardan hiç farkımız yok!. Hepimiz

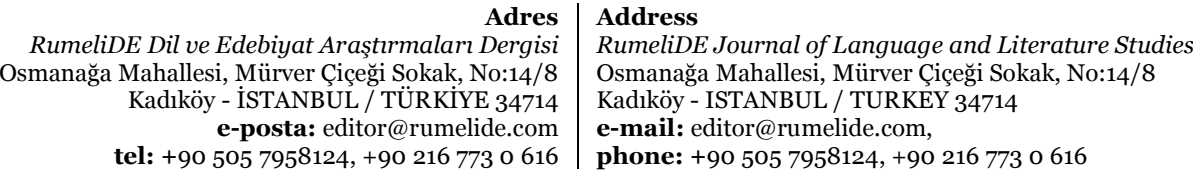


cılızlaştık. Masum yavrucukların hâlini sormayasın.. Bir deri bir kemik kaldılar.. Nedir bu Ümmet-i Muhammed'in başına gelenler?.” (Kestelli, 1925, s. 27)

Yaşanılan yoksulluğun sebebinin; devletin halkı soyması, ellerinde olan hayvanları, erkekleri, tahılları, giyecekleri ve yakacaklarını alması, Balkan Harbi'nin daha etkileri geçmemiş, halk kendini toparlayamamışken üzerine bir de I. Dünya Savaşı'nın gelmesinden mütevellit milletin iyice yoksulluğa sürüklenmesi olduğu ve halkın kötü yönetimi sorumlu tuttuğu anlatılıyor. "Hükûmetin zaten asker almaktan, köylüyü soymaktan başka işi gücü ne?.” gibi cümleler de mektuplarda çokça yer alır. Bu durum aslında insanların vatanlarını sevdiklerini lakin yüzyıllardır süregelen bitmek bilmeyen savaşlardan dolayı yıprandıklarını gözler önüne seriyor. Halk o derece yoksullaşmıştır ki halkı sefalet içindeyken, yiyecek ekmek dahi bulamazken sefa içerisinde yaşamasından dolayı kendi devletini suçlar hâle gelmiştir.

"Hükûmet bize bakacağına bizi soymaya çalışıyor.. Nihayet dâr-ı dünyâda bir tanecik kıymetli öküzümü zorla aldılar.. Kimsede iman, merhamet kalmamış.. Hem arslan gibi ciger-pâremi askere vereyim, hem de öküzümü.. Bu nerede görülmüş..” (Kestelli, 1925, s. 52)

İnsanların eğitim konusunda ikiye ayrıldığını anlatıyor. Kimisi okumaya, özellikle kızların okula gitmesine tamamen karşı iken kimisi de kendisi okuyamadığı için çok büyük sıkıntılar çektiğini, eksiklikler yaşadığını ve her insanın mutlaka okul eğitimi görmesi gerektiğini söylüyor. Halkın büyük bir kısmının eğitim görmemesinden dolayı okuma yazma oranının düşüklüğünden bahsediliyor. Doktorlara inançsızlıktan, karşı olmaktan ve devanın yalnızca hocalarda, dualarda ve türbelerde olduğunun düşünüldüğünden bahsediliyor. Durum öyle bir hal almıştır ki sanata yönelen insanlar; özellikle kızlar, toplumda kötü yola düşmüş bir kadın muamelesi görüyor. Sanatın gelişmesine, ilerlemesine imkân olmayan böyle bir ortamda insanların akıllarındaki tek şey açlıktan ölmeden diğer bir güne geçebilmektir. Bu durum aslında toplumdaki "Sanat karın doyurmaz." anlayışının kuvvetlenmesine sebep oluyor. Öyle ki o dönemde sanatçılar, bir diğer deyişle "çalgıcılar" halkın gözünde küçümsenip aşağılanacak insanlar olarak görülüyor. Bir genç kızın çalgı çalmasından öte öncelikli vazifesinin kocasının emri altında köle gibi hareket etmesinin olduğu düşünülüyor ki bunu düşünen kesim yine hemcinsleri olan kadınlardır. Yetişme şekli ve ortam baskısı aslında o dönemde imkânı olmayıp baş kaldırmayan genç kızların kaderini belirliyor. Eğitimin öneminin kavranamamasının yanında doktorların insanları tedavi etmesine rağmen yaptıkları işe saygı duyulmuyor:

"Bu doktor maskaralığı yetişmiyormuş gibi bir de başıma mektep zırıltısı çıkarıyorsun.. Artık sen sahihten çok oluyorsun.. Kıza ezberlettiğin şiir midir, ne herzedir, o saçmalar az gelmiş de şimdi mektebe vereceksin, öyle mi?. Utanmıyor musun sen? Kız çocuğa okumak ne oluyormuş?. İște meydanda.. Sen okudun, yazdın da ne oldun?.” (Kestelli, 1925, s. 83)

Yazar eserinde birçok tarihî olayı kaleme almıştır lakin bunlar arasında en fazla yer verdiği Ermeni olaylarıdır:

"Muharebenin ibtidâlarında Van taraflarında Ermeniler bütün Müslümanları, çoluk çocukları kesmişler.. Kızların, kadınların ırzlarına geçmişler.. Moskoflarla beraber bizimle muharebeye tutuşmuşlar.. Bizimkiler de mukabele etmişler; her taraftan Ermenileri köylerinden, memleketlerinden çıkarmışlar.. Amucen mektubunda şunları da yazıyor: "Bizim kasabadan tanıdığın Ermenilerin hepsi ağlaşarak, sızlaşarak, gittiler.. Hem oh çektim.. Hem de, Müslümanlık başka şeye benzemez, acıdım. Hele Magridiçe, Karabete ve familyaları halkına adeta yüreğim yandı. Eski bir meseldir: Fena komşunun yedi mahalleye ziyanı var, derler.. Çok doğru.. Van'daki canavar Ermenilerin cezasını şimdi bu zavallı adamlar çekiyor... Bize çok fenalık etti bu Ermeniler ama, Müslüman yüreği bu, işte yine acıyoruz, içlerinde sadık, iyi olanları da hiç yok değildi.. Hele bazıları bizlerle adeta hall-i hâmûr olmuştu. Neyleyim ki kendileri yaptılar, sebep oldular.. Başka bir devlet

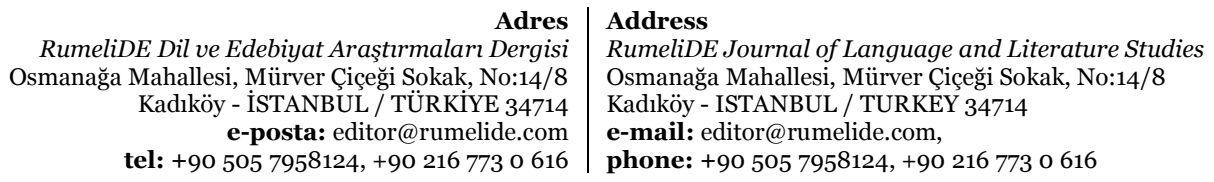


olsaydı muharebe zamanı hıyânetlik ettikleri içün toprağında sağ salim bir tane bile birakmazlardı..." (Kestelli, 1925, s. 58)

Anadolu insanı modern giyinmeyi, fes yerine şapka takmayı, kadınların erkekler ile yan yana gelmesini, aynı tramvayda seyahat etmesini, beraber dans etmesini hatta ve hatta aynı sohbet ortamı içinde bulunmasını, kısaca İstanbul'daki hayatı kendisine aykırı buluyor, o şehirden uzak durulması gerektiğini, dünyanın çivisinin çıktığını ve İstanbul'un bir günah şehri hâline geldiğini söylüyor. Buna karşllı bu durumu gayet normal bulan insanlar da mevcut.

"Ne olur? Anadolu'da okkalarla rakı içerek açık saçık kadınları oynatmak, onlara göbek attırmak ve sonra karşısına geçip bin türlü taşkınlıklar, rezaletler yapmak ayıp, günah olmuyor da kadın erkek beraber terbiyeli terbiyeli oynamak neye ayıp ve günah oluyormuş?..” (Kestelli, 1925, s. 114)

Alıntı olarak gösterilen çıkışması da aslında Anadolu insanının kuralları işine geldiği gibi, kendine göre koyup ona göre uyguladığını gösteriyor. Hatta bu zihniyet; yanlış olduğunu bildikleri hâlde doğruymuş gibi insanlara kabul ettirmeye çalışmalarından kaynaklı ortaya çıkan yanlışları, gayet normalmiş gibi göstermektedir. Hal böyle ki; kadın ve erkek sadece yan yana geldi, aynı ortamda seyahat etti diye günah sayarlardı. Kısacası hiçbir münasebeti olmamasına rağmen aynı yöne doğru giden kadın ve erkeğe bir suç işliyormuş gibi muamelede bulunan insanlara karşı verilen bu tepki, eserdeki en açık tepkilerden birisi olarak kabul edilebilir.

Eserin İkinci Kısım’ yazarın hakikate biraz daha yaklaştığı ve olayları biraz daha gerçek kişilere ve yaşanılanlara benzeterek anlattığı kısımdır. Birinci, İkinci ve Üçüncü Kısım'larda anlatılan olaylar birbirinin benzeridir lakin anlatan kişinin statüsü ve eğitim seviyesi farklıdır. İkinci Kısım'da ilk kısma göre biraz daha eğitimli insanların yazdığı mektuplar bulunmaktadır. İlk kısımda sıkça bahsedilen doktorlara tamamen karşı olma zihniyetinin eğitim seviyesi biraz daha yüksek olan insanlarda daha az bulunduğundan bahsedilir. Zamanında doktorlara itimat göstermeyip söylediklerini dinlemeyen insanların pişmanlıkları dile getirilir:

"Münire'nin ayakları romatizmadan topal gibi oldu.. O kadar rahatsız ki tarif edemem.. Vaktiyle doktorların dediklerini dinlemedik de halt ettik..” (Kestelli, 1925, s. 164)

Bu bölümde tıp daha da ilerlemiş ve insanlar gerçek devanın ne olduğunu görmüştür. İnsanlar bunu son çare olarak da olsa uyguluyordur. Uygulamanın sonunda doktorların en başından beri haklı olduğunu, kocakarıların rastgele otları onlara deva diye yutturduğunu anlamışlardır. Halkın bunu anlaması, insanların kafalarını kaldırıp gerçekleri görmeye başlamasının birer göstergesidir.
"Ben vesika ekmeği dedikleri o çamuru artık ağzıma koymuyorum.. Ne yaparsın, doktorların sözünü dinlemek lazım. Şimdi aklım başıma geldi ama, iş işten geçtikten sonra.. Evvelce gençliğimde doktorlara hiç ehemmiyet vermezdim; ne derlerse onun zıddını, aksini yapardım. Nihayet işte böyle genç yaşımda ihtiyar oldum.. Sana benim hâlim ibret olsun, kızım..” (Kestelli, 1925, s. 169)

Buna rağmen hâlâ doktorları gâvur olarak görüp karşı olan insanlar da bulunur. Bu durum aslında eski kafalılığın bir göstergesi olarak da gözler önüne serilmiştir. Her ne kadar aydınlanan bir kesimin önderliğinde doktorlara olan inanç artmaya başlasa da bu durumun ülke genelinde sıfırdan yüz oranına çıkması mümkün olmamıştır. Gençler biraz daha bilinçli yetişmeye başlayıp büyüklerini ikna etmeye çalışsa da aşağı yukarı her ailede doktor karşıtı bir birey bulunmaktadır. Durum böyle olunca bazı zaman hastalar gizli gizli doktora götürülür. Bazı zaman ise doktorlara güvenenler, doktor karşıtlarına sözlerini bir türlü geçiremediği için, hastalar, acı dolu kıvranışlarla ölüme mahkûm edilir.

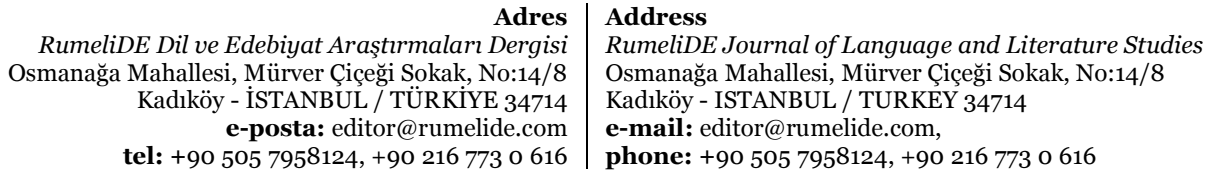

tel: +90 505 7958124, +90 2167730616 
Her ne kadar aydınlanmaya başlayan kesim ile cahil halk arasındaki görüş farklılıkları artsa da hepsinin hemfikir olduğu ve kafalarında soru işaretleri oluşturan bazı ortak sorunlar vardır. Türk Devleti'nin Almanlara güvenerek onların yanında savaşa girmeleri ne kadar sağlıklı idi? Almanya ekonomik ve askerî açıdan güçlü bir ülkeyken Türkiye savaştan savaşa koşan, yıpranmış bir ülkeydi. İki tarafın da yaşam şartları ele alındığında Türkiye'nin savaştan öte yoksullukla mücadele edeceği gözle görülebiliyordu. Çoğu mektubun temasını oluşturan konu da budur aslında. Yoksulluk, sefalet açlık... Halk her firsatta devletin kendilerini birilerine ya da bir şeylere yaranmak uğruna soyup soğana çevirdiğini ve bu soyma işleminin dur durak bilmediğini anlatıyor. Zaten kıt kanaat geçinebildikleri hanede tek dayanakları olan erkekleri bir bir askere alıp dayanaklarını kırdıklarından bahsediliyor. Eserde; "Savaş zamanıdır; erkekler cephede vatanı uğruna savaşır, şehit olur." düşüncesindeki insanların ellerinden bir de tek geçim kaynakları olan hayvanlarının alınmasıyla halkın ettiği isyanlara çokça yer veriliyor. Bütün bunlara rağmen halkın hâlâ bir ümidinin olduğu ve "Ne gelirse Allah'tan gelir." düşüncesine sahip olduğundan da bahsedilmiştir mektuplarda:

\begin{abstract}
"Her tarafı artık ateş sardı; bakalım sonu ne olacak?. Biz topal eșekle bu kervana hiç karışmamalıydık ama ne ise bir kere ok yaydan çıtı; hususuyla cihâd-ı ekber ilan olundu. Sirası mıydı değil mi idi, artık orasını Allah bilir. Hemen Kadir-i Mutlak sonunu hayırlı getire!.” (Kestelli, 1925, s. 144)

“..Malum ya, bu zamanda en kıymetli hediyeler boğaza, yiyeceğe müteallik olanlardır. Geçen gün bizim civarda bir sünnet dügünü oldu.. Oyuncak yerine hediye olarak sünnet çocuklarına has francalalar getirdiler.. Anlamalı, zamanın hâlini.. Allah vere de bu gidişle Ümmet-i Muhammed açlıktan kırılmayaydı.. Biz de herkes gibi artık öte beri satmaya başladık.. Muharebe böyle devam ederse bir seneye kadar bizim evde de eşya namına bir şey kalmayacak gibi..” (Kestelli, 1925, s. 158)
\end{abstract}

Yazar, ülkenin en güzel zamanlarını, en güzel kaynaklarını en güzel şekilde kullanıp sefasını süren devlet görevlilerinin, savaş zamanı geldiğinde halkın en ön safta vatanını müdafaa için yer alması gerektiği düşüncesinde olduğunu anlatır. Eserde, görevlilerin İstanbul'dan kaçmasından, halk mutlak bir tehlike ile karşı karşıyayken, yalnızca ailelerini tehlikeden uzaklaştırıp halkı tehlikeye atmalarından da bahsedilir. Muharebe kararını alıp halkı ateşe atan ve mağlubiyetin geleceğini anlayıp bu durumdan korkan, akabinde halkı bırakıp kaçan devlet görevlileri halkın hayal kırıklığına uğramasına neden olur. Onca sıkıntı arasında bir de yöneticilerin ihanetine uğrayan halk kin ve nefret ile dolar. Bu nefret halkın her kesiminden insanın ağzından yazılan mektuplarda çok açık bir şekilde görülebilmektedir.

Yeni nesil; eskilere nazaran okuma yazmaya daha fazla önem vermeye başlamıştır. Eğitimin bir toplumun her türlü şart altında ayakta kalabilmesi için ne kadar önemli bir konu olduğunun bilincine varmıştır. Lakin yine doktorlara olan yaklaşımlarda olduğu gibi, gerekirse bütün aile bu düşünceyi savunsa bile son karar yine aile büyükleri tarafından verildiğinden, asıl meselenin onları ikna edilip eğitim için gerekli şartların oluşturulmaya çalışılmasından bahsedilir.

\begin{abstract}
"Beyhude kıskançlıklar icat edeceğine, bu gibi vâhî fikirler, saçmalarla uğraşacağına seviyeni yükseltmeye çalışsan, kıymetli zamanını tahsile, mütâlaaya hasretsen daha iyi olmaz mı?. Yok, böyle hareket edersen günaha girersin.. Çünkü makul ve mantıki bir iş görmüş olursun.. Bilirim, esas kabahat sende değildir.. Sen de diğer birçok kadınlar gibi pederinin, hususuyla validenin, daha doğrusu, muhitinin kurbanısın.. Onların taassupları, onların cehaletleri, onların dar ve muzlim zihniyetleri seni böyle mahdûdü'l-fikir bıraktı..” (Kestelli, 1925, s. 160)
\end{abstract}

Birinci Kısım'da olduğu gibi bu kısımda da tarihî birçok olaydan bahsedilir. Bu olaylar hemen hemen aynı olaylardır lakin yine ilk kısımda olduğu gibi o dönemin kanayan yarası olan Ermeni Olayları biraz ön plana çıkmıştır. Ermenilerin zorla göç ettirilmesi ve giderken yaptıkları zulümler, katliamlardan dile getirilir. Ermenilerin; kadın, çocuk demeden ellerine geçen insanları yaşına ve cinsiyetine bakmadan yaşadıkları zulmün acısı ve nefreti ile öldürerek kaçtıkları anlatılır. Aslında yaşanan her

RumeliDE Dil ve Edebiyat Araşttrmaları Dergisi Osmanağa Mahallesi, Mürver Ciçeği Sokak, No:14/8 Kadıköy - ISTANBUL / TÜRKIYE 34714 e-posta: editor@rumelide.com tel: +90 $5057958124,+902167730616$
Address

RumeliDE Journal of Language and Literature Studies

Osmanağa Mahallesi, Mürver Çiçeği Sokak, No:14/8

Kadıköy - ISTANBUL / TURKEY 34714

e-mail: editor@rumelide.com,

phone: +90 $5057958124,+902167730616$ 
kötü olayda olduğu gibi bir halkın her kesimi bu suça ortak olmayı bir bölümü kendi hâllerinde yaşam mücadelesi vermeye çalışmaktadır. Suçluların aslında Van Ermenilerini olduğu, diğer Ermeniler arasında iyi insanlar olmasına rağmen Van Ermenilerinden dolayı onların da bu vahşi zulme ortak olmuşçasına damgalandıklarını ve kuru otların arasında yanan yaş otlar gibi başlarının yandığı anlatılır:

"Erzurum vilayeti tamamen bitmiştir. Van'da yaptıkları vahşiyane zulme mukabele oldu ama bazı yerlerde de az çok şan-ı İslâmiyyet'e yakışmayacak derecede muameleler vuku buldu.. Tehcîri, teb'îdi, asileri şiddetle te'dîbi anlarım, ve çok muvâfık bulurum. Fakat haksız yere bî-günâhları tecziyeyi hangi milletten ve dinden olursa olsun, büyük bir günah telakki ederim. Onlar vâkıâ her türlü canavarlıkları yapıyorlar. Ve lakin biz de yaparsak sonra onlara benzemiş olmaz mıyız? Mamafih müsebbibleri yine kendi millettaşları..” (Kestelli, 1925, s. 194)

Üçüncü Kısım diğer iki kısımdan yapı olarak biraz farklılık göstermektedir. İlk iki kısımdaki mektupların herhangi bir başlığı ya da ismi bulunmamaktadır. Bu kısmı diğerlerinden ayıran en büyük özellik budur. Yazar her mektuba tek tek isim vermiştir. Bu isimler; "Meş'ûm Bir Sima", "Şen Bir Zekâ", "Müdafaa”, "Sünbüle”, "İsyan”, "Buhran”, "Zavallı Vatan”, "Kız Talebeler Arasında”, "Mektep”, "Faziletin Kudreti", "İdeal Talebe", "Medeniyete Doğru”, "Bir Seyahatin Hikâyesi", "Sabire'nin İntiharı", "Vatan ve Aşk”, "Siyah Mektup", "Nur Veren Kız” ve "Yeni Hayat”tır.

"Meş'ûm Bir Sima” başlıklı mektup küçük bir hikâye olarak da sayılabilir. Mektupta, babasının biriktirmiş olduğu altınları zevk ve sefa için harcayan bir genç anlatılır. Kaybedilen Balkan Harbi'nin etkilerinden bahsedilen mektupta Türklerin I. Dünya Savaşı'na Almanlardan etkilenip onlara güvenip girdiği anlatılır. Ülkenin zaten bitik bir durumda olduğu, savaşın kaybedilse de çok fazla etkilenilmeyeceği lakin kazanılırsa bunun ülkeye bir şeyler katabileceği konusuna da değinilmiştir. Bu durum bir nev kumar oynamaya benzetilir:

\begin{abstract}
"Onlarda o külhanlık, o küstahlık, o komitacllı ve irfansızlık varken hatta bütün dünyaya ilân-ı harb etmekten çekinmezler.. Bizim gibi sessiz bir milletin mukadderâtı ile, tâli’î ile mutantan bir tarzda kumar oynamaktan, "Poker"de olduğu gibi blöf yapmaktan tatlı bir şey olur mu?.. Milleti batırırlarsa ne kaybederler?. Hiç.. Velev ki yüzde bir ihtimal olsun, çıkarırlarsa çok şey kazanırlar.. Bedava bir müheyyic kumar... Bedava bir sansasiyonel oyun!.” (Kestelli, 1925, s. 360)
\end{abstract}

"Şen Bir Zekâ" başlıklı mektupta Türkçenin düzgün ve kurallarına göre kullanılmasına gösterilen özenden ve Türkçenin değerinden bahsediliyor. Eskiden gayet güzel kullanılırken şimdilerde bozulmaların meydana geldiğine dikkat çekilir. Çok büyük kayıların ve savaşların olduğuna dair söylentilerin dolandığından, bunların asılsız olduğundan bahsediyor. Mektubu yazan kişi; belli bir askerî geçmişi olan donanımlı erlerin Çanakkale'de değil de Ruslara karşı savaştırılması gerektiğini düşünüyor.

"Müdafaa" başlıklı mektupta görücü usulü evlenmenin genç kızlar için bir kumar olduğuna ve çoğunun hayatının bu sebepten ötürü karardığına yer verilir. Mektupta, bu usuldeki evliliklerin çok büyük bir yanlış olduğu ve eğer görücü usulü evlenme ile memnun ve mesut olunabilseydi dünyadaki en mutlu milletin Türkler olacağı, ayrıca herkesin evleneceği kişiyi kendisinin seçmesi gerektiği, mektubu yazan kişinin görücü usulü evliliğe kurban gittiği düşüncesinde olduğu ve kız kardeşinin de başının bu sebepten yanmamasını istediği dile getirilir. İki insanın ruhu birbirine uyuşmadıktan nikâhın da hacı hocanın dualarının da yeterli olmayacağı dile getirilmiştir. Nikâhta değil ruhların uyuşmasında keramet olduğu söylenir. Kadınların öneminin anlaşılmaya başlandı̆̆ından ve inkılaplarla birlikte kadınların toplum içerisinde daha fazla yer aldığından; düğünlere, sergilere gidebildiklerinden bahsedilir. Aslında bu bölümde; halkın içinde bulunduğu fiziki savaşın yanı sıra, diğer mektuplarda da

\footnotetext{
RumeliDE Dil ve Edebiyat Araşttrmaları Dergisi Osmanağa Mahallesi, Mürver Ciçeği Sokak, No:14/8 Kadıköy - İSTANBUL / TÜRKIYE 34714 e-posta: editor@rumelide.com tel: +90 505 7958124, +90 2167730616 
bahsedildiği üzere günün düşünce ve yaşayışına ayak uyduramayan kimseler ile yenileşmeye, modernleşmeye başlamış kimselerin fiziki olmayan savaşı anlatılır.

"Sünbüle”de mektubu yazan kişi; her milletin sonunu, ülkeyi kötü yöneten siyasilerin sözleri ardından koyun sürüleri gibi mezbahaneye gitmeye benzetiyor.

"İsyan" adlı mektupta savaş sırasında ailelerin yoksulluk ve sefalet çekmeleri anlatıldıktan sonra aynı mektupta yiyecek ekmek bulamasa bile okuluna devam eden bir gençten bahsediliyor. Türklerin ticarette çok geride kaldıkları ve mazinin boşluğunu doldurmak için herkesin ticaretle uğraşmaya çalıştığı, bu sebepten insanların ticaretten tiksindiği anlatılıyor. Binlerce insanın açlıktan ve yoksulluktan öldüğü söyleniyor. Ayrıca ticaret yapmanın okullarda öğrenilemeyeceğine, sahada yani ticaret yapa yapa öğrenileceğine değiniliyor.

"Buhran"da vahşi ruhlu üfürükçü babaların, eski fikirli cahil ebelerin millete yaptığı fenalıkların derecesi anlatılıyor. Doktorların halka sözü geçmezken kocakarıların, üfürükçülerin tek bir sözlerinin bile büyük önem teşkil ettiği söyleniyor. Eskiden kocaların hanımlarının onlara yetmediğini söyleyerek, ikinci eşleri almak için zemin hazırladıklarından bahsediliyor. Fransa ve Türkiye karşılaştırması yapılarak Fransa'daki ve Türkiye'deki çocukların yaşam şartları kıyaslanmış. Orada doğumun az olmasına karşın doğan çocukların yaşayabilmesi için gerekli şartların sağlandığına, Türkiye'de ise doğan çocukların sağlık imkânlarının yetersizliği nedeniyle öldüğüne dikkat çekilmiş. Görücü usulü ile evlendirilen insanların birbiriyle anlaşamadığı için ruhlarını doyuracak insanlara yöneldiklerinden ve eşlerin birbirlerini aldattıklarından söz edilmiş. Mektup yazarı, erkeklerin bulduğu her firsatta hanımlarını boşadıklarını söylüyor:

\begin{abstract}
"Aşağı tabakada ve hatta vasatî muhitte bulunan kadınlarımız öyle muzlim bir zihniyete, öyle elîm bir hâlet-i rûhiyyeye maliktirler ki doktorların, mektepten çıkmış kabilelerin en fennî tavsiyeleri, en makul sözleri o zavallı dimağlarda maalesef hiçbir tesir husule getiremez.. Fakat ihtiyar kadınların, fakat cahil ebelerin ve hocaların, hele o ma'hûd üfürükçü babaların ufak bir işareti, bir ihtarı onlara en gülünç, en feci tedbirleri, ilaçları tehâlükle yaptırmak içün kâfi gelir..” (Kestelli, 1925, s. 394-395)
\end{abstract}

"Zavallı Vatan” Almanya'da ziraat biriminde çalışan bir Türk'ün kaleme aldığı bir mektuptur. Türkiye'nin durumuna bakıldığında çalışma konusunda çok büyük eksiklerin olduğu belirtilir. Çalışmanın ne kadar önemli olduğu vurgulanır. Almanya savaşta olmasına rağmen üretim devam edebiliyor ve insanlar rahat içinde yaşayabiliyor. Neden aynısını kendi milletinin yapamadığını sorguluyor ve bu vaziyetten ötürü üzüntü duyuyor. Ziraatın bilgisizce ekip biçmek olmadığına değinilir. Ziraat için nitelikli ve donanımlı çiftçilerin yetiştirilmesi gerektiği, ülkedeki kötü hâlin yalnızca bu yol ile sona erebileceği ifade edilir. Yazar: "Almanya'daki ziraat Türkiye'de olsaydı savaş sırasında açlıktan ölenler olmaz ve daha uzun süre savaşabilirdik.” der. Yani Türk milletinin sadece düşmanla değil açlık ve yoksullukla da savaştığı vurgulanır... Yazar, hükûmetten şikayetçi olur ve bu hükûmetin Türk halkına yakışmadığını belirtir. Avrupalılaşmaktan ve kadının toplum içindeki öneminden bahsediyor.

"Kız Talebeler Arasında" adlı mektupta her şeyin pahalı olması ve yoksulluğun had safhada oluşu anlatılır. Bu dönemde; okullarda fiziki olarak yenilenme çalışmalarına gidilmiştir, kadınlar çalışma hayatında, donanmada, devlet dairelerinde yer almaya başlamıştır, insanlar artık istedikleri gibi giyinmekte özgür hale gelmiştir, millî banka kurulmuş ve miladi takvime geçilmiştir. Bunun yanı sıra; yaşlı kadınlar genç kızların eğitim görmesine karşı çıkmış, din adamları kıyafet devriminin aksi yönünde vaazlar verip insanların sinemaya ve eğlence yerlerine gidip camiye gelmemelerinden şikayetçi olmuşlardır. Yazarın mektubu ağzından kaleme aldığı; kişi böyle din adamlarının dinlenilip,

RumeliDE Dil ve Edebiyat Araşttrmaları Dergisi Osmanağa Mahallesi, Mürver Çiçeği Sokak, No:14/8 Kadıköy - İSTANBUL / TÜRKIYE 34714 e-posta: editor@rumelide.com tel: +90 $5057958124,+902167730616$
Address

RumeliDE Journal of Language and Literature Studies

Osmanağa Mahallesi, Mürver Çiçeği Sokak, No:14/8

Kadıköy - ISTANBUL / TURKEY 34714

e-mail: editor@rumelide.com,

phone: +90 5057958124 , +90 2167730616 
ilim irfan sahibi olmak isteyen kızların mekteb-i tıbbiyyeye kabul edilirken bu vaziyetten korku duymalarından şikayet etmiştir.

Görevi yeni devralmış bir okul müdürünün ağzından yazılan "Mektep” adlı mektupta, yazar okulların fiziki olarak kötülüğüne yer veriyor. Burada bazı eski hocaların ve görevlilerin temizlikten uzak olmasından dolayı okulun yıkılıp döküldüğünü, harap bir halde pislik içinde kaldığını söylüyor. Temizliğin imandan geldiğini söyleyip temizlikten bihaber Müslümanlardan yakınıp gayr-i Müslimlerin Müslümanlardan daha temiz olduğu belirtilir. Anlatıcıya göre, vaziyet öylesine kötüdür ki temizliğin simgesi olan hamamlar bile fazlasiyla pistir.

Mektubu yazan kişi, İstanbul ile Anadolu arasında çok büyük farklar olduğundan, Anadolu'da yaşayan halkın fakirliğinden ve kıyafet yokluğundan bahseder. Halkın cahilliğinden ve çocuklarına olan ilgisizliğinden, öğrencilere verilen eğitimin kalitesizliğinden, üst sınıflara geçen öğrencilerin bile doğru düzgün okuyamadığından yakınır. Çocukların hayata dair en ufak bir heyecanının bile kalmadığını ifade ettikten sonra muallimlerin okuttukları dersin amacını dahi bilmediklerini söyler.

"Faziletin Kudreti”, kadınların çocuklarını doyurabilmek için iffetlerini sattığını, buna rağmen padişahların ve yönetici zümresinin bolluk içinde yaşadığını, bu bolluk içinde yaşayan zümre için garibanların cephede savaştığını ileri süren bir mektup. Mektupta her kötülüğün elbette bir cezasının olacağına, tarihin bu cezalarla dolu olduğu düşüncesine yer veriliyor. Bazı insanların çok fakirken bazılarının da çuvalla para sakladığından yani gelir dă̆ılımının orantısız olduğundan bahsediliyor. Cahil bir hükûmete sahip olan her halkın felaketlerle karşlaşmaya mecbur olduğu, cehaletten kurtulmadığımız sürece Almanya’nın Türk hükûmetinin müttefiki değil amiri olacağı dile getiriliyor.

"İdeal Talebe" adlı mektupta padişahların savaşlarda halkını düşünmeyip ölümlerine sebep olduğunu lakin hiç olmazsa barış zamanında halkını düşünmeleri gerektiğinden ve sağlık şartlarının çok kötü olduğundan bahsediliyor. Yazar, mektubunda geçmişten beri Türk milletinin çalışmaktan uzak olduğunu, Avrupalıların ise sürekli çalıştığını ve bu sayede de geliştiklerini belirtiyor. Spor yapmayan insanların, spordan uzak bedenlerin sağlıksız olacağını, sağlıksız bedenlerin kafalarının da sağlıksız olacağını dile getiriyor. Bir kafadan verim alabilmek için ona sağlam bir vücut vermemiz gerektiğinden bahsediyor. Bu duruma istinaden "en verimli toprak bile bir süre sonra ürün vermez" benzetmesi yapılıyor. Sadece zekânın yeterli olmadığı, zekâ ile birlikte vücudun da dinç ve sağlıklı olması gerektiği, yalnızca bu sayede insanların başarıya ulaşabileceği uyarısı yapılıyor. Ülkede adam kayırmanın farkında olduklarını, bu yüzden çok yetenekli muallimlerin gereken yerlere gelmemesinden yakınılıyor.

Bu mektupta Avrupa ile eğitim kıyaslaması da yapılmış, Avrupa'da öğrencilerin birer çiçek edası ile yetiştirildiği, Türkiye'de ise buna hiç özen gösterilmediği anlatılmıştır. Eğitim sistemi düzelmezse Türk milletinin selamete çıkmasının mümkün olmadığı, aile terbiyesinin de okul konusunda çok önemli bir etken olduğunu belirtilmiştir. Eğitimlerin öğrenmeye yönelik değil de ezberletmeye yönelik olduğunu söyleyerek bunun nedenini donanımsız öğretmenlere bağlamıştır.

"Medeniyete Doğru” adlı mektubun başlı̆̆ından da anlaşılacağı gibi son zamanlarda yapılan yeniliklerle ülkenin medeniyet seviyesinin artırıldığından bahsedilir. Savaşın bitmesi, tarımın normale dönmesi ve mahsulün iyi alınmasının yanı sıra tarım vergisinin kaldırılması sayesinde Anadolu insanı rahatlamıştır. İnsan sağlı̆̆ına önem verilmeye başlandığından salgın hastalıklarla mücadele edilmeye hız verilmiştir. Ziraat için de ilk defa şuurlu bir ziraat modeli ortaya konduğu ve gelişi güzel değil de

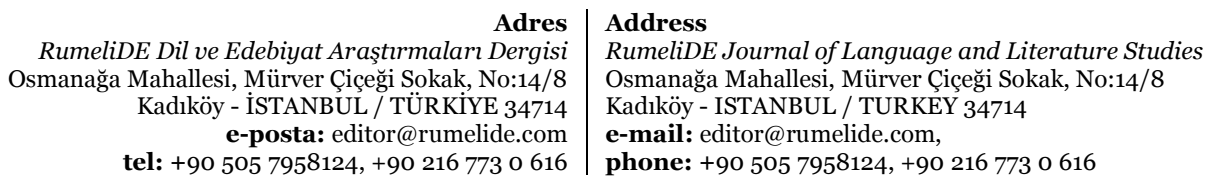


ihtiyaca yönelik bir ziraat siyaseti uygulandığı anlatılır. Pamuk ve zeytinyağında epeyce yol kat edildiği ama bu ürünlerin daha da geliştirilip birkaç ülkenin daha önüne geçilmesi gerektiği dile getirilir. Mektupta, neredeyse yapılan her şeyin günah olduğunu düşünen cahil kesimin aydınlanmaya başladığından; Dünya Savaşının çok gereksiz bir savaş olduğundan, kazanan ve kaybeden tarafların eline hiçbir şey geçmediğinden yalnızca bir sürü insanın ölüp bir sürü boş harcama yapıldığından bahsedilir. Mektup yazarı, Mustafa Kemal Paşa'nın dini kullananların karşısında olduğunu ve bu din kullanma düzenini sona erdirmeye çalıştığını söyler.

“Bir Seyahatin Hikâyesi”nde, mektubu yazan kişi, İstanbul'un vaziyetini bir gezgin edası ile anlatır ve vapurların kötülüğünden ve tehlikesinden bahseder. Mektup yazarına göre vapurlara kapasitesinin üzerinde yolcu alındığından zaten sağlam olmayan vapurlar çok büyük tehlikeler arz etmektedir. Bu mektupta tiyatro salonları üzerinde çok fazla durulmuş, tiyatro salonlarının havasızlı̆̆ından, basıklığından ve içlerinde sigara içilmesinden mütevellit oluşan kasvetten bahsedilmiştir. Mektubun bir bölümünde; tiyatro izlemeye gelen üç ecnebinin, içeride on dakikadan fazla duramayıp çıktığı ve aralarında tiyatro salonlarının ne kadar kötü olduğuna dair konuşmaların geçtiği ifade edilmiştir . Türk milletinin sanata ve yeniliklere aç olduğundan ancak kendilerini geliştirmek için hiçbir girişimde bulunmadıklarından bahsedilmiştir. Mektupta İstanbul'un dar ve fakir sokaklarından; Sirkeci Garı'nın, Galata Rıhtımı'nın kirliliğinden ve çirkinliğinden, bu yerlerin temiz tutulması için hiçbir çaba gösterilmeyip hunharca kullanılmasından bahsedilir. $\mathrm{Bu}$ durum da halkın ve dışarıdan gelen insanların gözünde kötü bir izlenim bırakmaktadır.

"Sabire'nin İntiharı" adlı mektupta; ailesinin ilgisizliğinden; sanata ve musikiye karşı oldukları için kızlarının bunları icra etmesine izin vermediklerinden dolayı Sabire isimli gencecik bir kızın, kalbine slktığı bir kurşun ile intihar edişinden duyulan üzüntü anlatılır. Kadınların cephede düşmanla birebir olmasa da cephe gerisinde askerlere yardım ederek savaştığı ve savaşan ordunun ilk defa kadınlığın ebedi kudretini, içtimai füsununu, tatlı ve diriltici şefkatini duyduğu dile getirilir.

"Vatan ve Aşk", Anafartalar'da yaralanan bir askerin onu tedavi eden hemşireye olan aşkını ve bu aşk sayesinde iyileşip cephelere dönebildiğini anlatan bir mektup. O dönemdeki Türk kadınlarıla başka milletlere mensup kadınlar arasındaki farklara değinir:

\begin{abstract}
"Gayr-i Müslim kadınlar lokantalara, gazinolara, tiyatrolara, sinemalara giriyorlar; zevcleriyle bahçelerde, tenezzüh yerlerinde hava alıyorlar, vesâ'it-i nakliyyede istedikleri mu’tenâ yerleri işgal ediyorlar.. Vatanın hakiki anaları, millet-i hâkimenin kadınları ise sümsük sümsük, süfliyyet ve sefalet içinde topraklar, taşlar, çayırlar üstünde oturuyorlar; yahut küstah erkeklerin müstehcen sözleriyle kulakları tırmalanmak içün köhne mesire yerlerinde dolaşıyorlar.. Ne adi, ne acıklı bir manzara, bir manzara-ı tezâd değil mi?.” (Kestelli, 1925, s. 543-544)
\end{abstract}

“Siyah Mektup”ta vatanın her yanının işgal altında olduğu, özellikle İstanbul'un büyük bir felaket içinde olmasının halkın ruh hâlini bir uçuruma sürükleyip insanların aklında intihar fikirlerinin yer edindiği anlatılır. Hükûmetin doymak bilmeyen önde gelenlerinin düşmanın karşısında durup ülkesini koruması gerekirken bir de onlara para karşılığında ülkeyi sattıkları, savaşa girmenin zaten akla mantığa sığmadığı ayrıca İstanbul'un şu anki hâlinin Bizans'ın son günlerine benzediğini ileri sürülür. Ayrıca İzmir meselesinin geçmişten beri Yunanlılarla mücadele edilen bir mesele olduğu da anlatılır. Bunun yanı sıra Sivas Kongresi'nin Anadolu'yu ateşleyip halkta coşkuya ve heyecana sebep olduğu lakin her şeyden önemlisinin dünya barışı olduğu anlatılır. Mektup yazarı, düşmanın İstanbul'da bulunan güzel evleri işgal edip ev sahiplerini evlerinden zorla çıkarttığını, hükûmetin buna karşı bir şey yapmadığı gibi bir de düşmanla iş birliği yaptığını, bu da yetmezmiş gibi İstanbul'un asayişini İngilizlere bıraktığını üzülerek dile getirir. İngiliz askerlerin Türk halkına kötü davrandı̆̆ı, peçeli

\begin{tabular}{r|l} 
Adres & Address \\
RumeliDE Dil ve Edebiyat Arastirmalarl Dergisi & RumeliDE
\end{tabular}

Osmanağa Mahallesi, Mürver Çiçeği Sokak, No:14/8 Osmanağa Mahallesi, Mürver Çiçeği Sokak, No:14/8

Kadıköy - İSTANBUL / TÜRKIYE 34714 Kadıköy - ISTANBUL / TURKEY 34714

e-posta: editor@rumelide.com

e-mail: editor@rumelide.com

tel: +90 505 7958124, +90 2167730616 phone: +90 505 7958124, +902167730616 
kadınlara sataştığı, Türklerin kendi vatanlarında adeta birer mülteci muamelesi gördüğü, bir sürü zulüm ile karşı karşıya kaldığı anlatılır.

"Nur Veren Kız” adlı mektupta Büyük Ferdâ isimli kadınlar komitesinden ve kadınların hayatın içinde daha fazla yer alıp öğrenimlerini tamamlayıp öğretmen, doktor ve hemşire olduklarından ayrıca daha fazla kadının okuyup hayatın içinde daha fazla yer almaları gerektiğinden bahsedilir:

"Biz Anadolu’yu uyandırmak ve ısındırmak, şen ve mesut yapmak içün asrın ve fennin istediği tarzda irfan kadınları yetiştirmeliyiz. O her şeyden güzel, o her şeyden kudretli hakikati ve istikbali ancak bu tarzda kadınlar kucaklayacak ve asil medeni ve fikrî inkılabı, Büyük Ferdâ'yı şimdi yetiştireceğimiz nesil yaratacaktır.” (Kestelli, 1925, s. 569)

Avrupa ve Amerika'daki diğer kadın cemiyetleriyle iletişime geçilmiş, mektuplar yazılmıştır. Büyük Ferdâ Cemiyeti'nin ismi bütün dünyaya duyurulmaya başlanmış ayrıca eğitim görmeleri için Avrupa'ya kız öğrenciler gönderilmiştir. Bunun yanı sıra şiddet görüp zorla evlendirilmeye çalışılan kızlara destek olunup koruma altına alınmaları sağlanmış, sadece kalacak yer bulunmakla yetinilmeyip hukuki yollardan da haklarının korunması için çalışmalar yapılmıştır.

"Yeni Hayat" adlı mektup yazılış açısından bir çeşit kurtuluş mektubu niteliği taşır. Yabancılar yurttan çıarılmış, vatanın hakimiyeti tekrar sahibine yani Türklerin eline geçmiştir. Türklerin bununla beraber ticareti de eline almaya başladığı, yabancı dükkânların iflasa sürüklendiği anlatılır. Kadınların önemi giderek artmış, kadın işçiler çoğalmış, yokluk ve sefalet büyük bir hızla azalmış, kadınlar hayatın içinde daha fazla yer almaya başlamış, tramvaylardaki perdeler kalkmış, kadın ver erkeklerin aynı şartlarda, aynı ortamlarda yolculuk yapmasının temelleri atılmıştır. Şimdiye kadar dünyanın hiçbir yerinde bu büyüklükte köklü yenilikler yapmayı başarıp halka kabul ettirebilen bir liderin olmadığı ileri sürülür. Mektupta, sadece Mustafa Kemal gibi bir dâhinin bunu başarabildiği, Mustafa Kemal'in halkı büyük bir cehaletten kurtardığı ve bundan dolayı yaşadı̆̆ı sevinç dile getirilir. Atatürk'ün gerçekleştirdiği ilke ve inkılapların yanı sıra yönetim merkezinin İstanbul'dan Ankara’ya taşındığı, din adamlarının siyasetten uzaklaştırıldığı, vapurların yenilenip güzelleştirilerek dünya standartlarının üzerine çıkarıldığı anlatılır:

"Biz Türk kadınları, diyordu, şimdiye kadar insandan başka bir şey imişiz de haberimiz yokmuş! Dünkü yâbis hayata, dünkü hâileli esaretle bugünkü hür ve münşerih hayatımızı düşündükçe rüya görüyor gibi oluyorum. Meğer bizim evvelce cidden hayvandan bir farkımız yokmuş!” (Kestelli, 1925, s. 594)

Ülkede yaşayan bütün kadınların Mustafa Kemal Paşa'ya minnettar oldukları ve bu geniş hürriyete layı oldukları anlatılır. Mektup yazarı, mektubunda; yüce Türk kadınının, hürriyetin vatani ve insani hedefini tamamen kavradı̆̆ını, anlayabildiğini ve bunu fiilen ispat ederek kanıtlayabileceğini söyledikten sonra Türk Ocakları'nın vazifesinden bahseder:

"Fikrimce şimdi Türk Ocakları'nın vazifesi medeniyet inkılabında halka rehber ve mürşit olmak, büyük inkılabın ruhunu iyi işlenmemiş Türk dimağlarına sindirmek, artık benliğini bulan Türk’ün bedenî ve medeni seviyesini yükseltmek içün icap eden fedakârlığı yapmaktır. Türkçülüğün, milliyetperverliğin hedef-i aslîsi çilekeş Anadolu'nun umrân ve irfanını, medeni ve iktisadi kudretini temin olmalıdır..” (Kestelli, 1925, s. 602)

Bütün bu gelişmelere ve halkın rahatlamasına rağmen kitap satışlarının azlığından ve halkın eğlenceye, zevk ve sefaya daha fazla önem vermesinden şikâyet edilir. Mektupta, ülkeyi yönetecek vekillerden beklentileri şöyle sıralanır:

RumeliDE Dil ve Edebiyat Araşttrmalar Dergisi Osmanağa Mahallesi, Mürver Çiçeği Sokak, No:14/8 Kadıköy - İSTANBUL / TÜRKIYE 34714 e-posta: editor@rumelide.com tel: +90 $5057958124,+902167730616$
Address

RumeliDE Journal of Language and Literature Studies

Osmanağa Mahallesi, Mürver Çiçeği Sokak, No:14/8

Kadıköy - ISTANBUL / TURKEY 34714

e-mail: editor@rumelide.com,

phone: +90 5057958124 , +90 2167730616 
“... muhteris ve mütebasbıs, mihver-i tefekkürâtı esen rüzgâra, tebellür eden kuvvet ve menfaate göre döner cinsten olmamalı ve hususuyla daima, ama daima menâfi'-i milliyyeyi şahsi ve zümrevî menfaat ve ihtirasların çok fevkinde tutabilmek celâdetini, kahramanlığını gösterebilecek pak ve mert bir tabiatta yaratılmış bulunmalıdır.” (Kestelli, 1925, s. 607)

Düğünlerin artık daha modern ve gösterişli yapılıp düğünlerde kadın ve erkeklerin rahatça dans edebildiği hatta bunların günlerce sürebildiğinden bahsedilir. İnsanların futbol, tenis gibi sporlara yöneldiği ve sosyal faaliyetlerini arttırdığı söylenir. Bütün bu yenilikler meydana gelirken bir yandan da isyanların ortaya çıtığına bunlardan en büyüklerinden birinin Şeyh Said İsyanı olduğuna yer verilir. Şeyh Said'in yargılanırken mahkemesinde bulunan bir adamın dilinden olayların akıbeti, nasıl yargılandığı, neyle suçlandığı ve bu kabul edilemez isyan ile vatanına ne kadar zarar vermiş olduğu anlatılır.

Yazar, mektubu; bütün ümidin, bundan sonra gelecek nesilde olduğunu ve bundan sonra gelecek neslin zihniyetinin her şeyi belirleyeceğini belirterek bitirir.

\section{Hayat ve Mektuplar'da Zihniyet}

Hayat ve Mektuplar adlı eser üç farklı kısımdan oluştuğu gibi bünyesinde üç farklı zihniyeti barındırır. Bu sebeple eserin zihniyeti üç farklı kısımda ayrı ayrı incelenebilir.

Birinci Kısım: Bu kısımdaki mektuplar daha önce de belirtildiği gibi köylünün, askerin kısacası halk tabakasına mensup insanların ağzından yazıldığından tam bir cahillik, temizlik, saflık ve fikren karanlık bir yapı içerir. Gelenek, göreneklerine bağlı insanlar; din adamlarının ve hükûmetin sözüne itimat edip doğru olup olmadığını sorgulamadan, kendi fikirlerine önem vermeden, büyüklerinin uygun gördüğü şeyleri kabul edip uygularlar. İnsanların bir bölümü ruhen tam bir bunalım içindedir ve akıllarında daima intihar etme fikri yer alır. Doktorlara, hemşirelere, öğretmenlere itimat etmeyip geçmişten beri süregelen yöntemleri uygularlar. Hastalıkların tedavilerini tıpta değil de dualarda, tekkelerde, hocalarda arar, doktorlara ve hemşirelere adeta birer gâvur gözüyle bakar, öğretmenlerin öğrettiği şeyleri insanları yoldan çıkaran şeyler olarak kabul eder, sanata ve ilme bütünüyle karşı çıkarlar. Çağdaşlaşmaya tamamen kapalıdırlar. Ekonomik olarak buhranda olunan bir dönemde hayatlarını idame ettirmeye çalışan bu insanlar, her şeyden önce karınlarını doyurup yatacak sıcak bir yataklarının olmasını amaçladıkları için çok fazla bir şey yapabilme, kendilerini geliştirebilme imkânına da sahip değildirler.

İkinci Kısım: Bu kısımda zihniyet biraz daha çağdaşlaşmaya açıktır. Mektuplar kendi fikirlerine sahip olan insanların ağzından yazılmıştır. Durum her ne kadar böyle olsa da bu bölümde, geçmişe bağlı olan ve çevresinde olup bitenleri tam anlamıyla sorgulayamayıp fikirlerini beyan etmekten çekinen insanların ağzından yazılmış mektuplar da bulunur. Bu mektubun yazıldığı dönemde ve coğrafyada yaşayan insanlar; sanata ve ilme yönelmenin insanı dinsiz yapmayacağı aksine insanı geliştirip vatanına ve milletine daha faydalı bireyler hâline getireceği düşüncesi hâkim olsa da bu düşüncelerini büyüklerinin korkusundan dile getiremezler, getirseler de onlara karşı bir savaş vermeleri gerektiğinin farkındadırlar. Eserin bu kısmında bahsedilen insanların ekonomik güçleri ilk kısma göre biraz daha iyi olsa da yine yeterli olmadığı için tam anlamıla savaş ve hayatta kalma psikolojisi ile hareket ettiklerinden kendilerini geliştirmeye yönelik faaliyetlere girişmezler. İki farklı kafa yapısı hakimdir: eski ve yeni. Eskiler yine birinci kısımdaki insanlarla tamamen aynı düşüncede iken biraz daha genç olanlar modernleşme taraftarıdırlar. Sözün bittiği yer; hacılar, hocalar, türbeler,

\begin{tabular}{r|l} 
Adres & Address \\
RumeliDE Dil ve Edebiyat Araştırmaları Dergisi & RumeliDE Journal of Language and Literature Studies \\
Osmanağa Mahallesi, Mürver Çiçeği Sokak, No:14/8 & Osmanağa Mahallesi, Mürver Çiçeği Sokak, No:14/8 \\
Kadıköy - İSTANBUL / TÜRKIYE 34714 & Kadıköy - ISTANBUL / TURKEY 34714 \\
e-posta: editor@rumelide.com & e-mail: editor@rumelide.com, \\
phone: +90 505 7958124, +90 2167730616
\end{tabular}


tekkeler olmasına rağmen doktorların, ilmin ve sanatın değeri az da olsa bilinir ve bu doğrultuda birtakım çalışmalar yapılır.

Üçüncü Kısım: Bu kısımda sosyal, ekonomik ve siyasi yapıda ilk kısma göre epeyce bir ilerleme kat edilmiş, insanların refah seviyeleri yükseltilmiş, tıbba, ilme, irfana karşı bir güven kazanılmış, sağlık konusunda din adamlarının söz hakkı azaltılmıştır. İnsanlar her şeyin bilincine varmaya başlamış, yaşadıkları hayatın kalitesinin artması için çabalar göstermişlerdir. Geçim sıkıntısı azaldığından insanlar karınlarını doyurma aşamasını geçip beyinlerini ve ruhlarını doyurma çabası içine girmiştir. $\mathrm{Bu}$ durum ise insan eşitliğinin, eğlenceye ve sanata ihtiyacın fark edilmesini sağlamış; insanları modernleşmeye itmiştir. İnsanların ruhlarına bir ferahlama ve rahatlama gelmiştir. Siyasi yapı olarak Cumhuriyet'e geçilmiş, hükûmet ve padişah odaklı yönetimden halk odaklı yönetime geçilmesinden dolayı insanların ihtiyaçlarını karşılayacak ve refah seviyesini arttıracak yöntemlere yönelik çalışmalar yapılmaya başlanmıştır. İnsanların sağlı̆̆ı, refahı ön planda olduğundan insanlar insan yerine koyulduklarının farkına varıp hayata ve ülkelerine daha fazla tutunmuşlardır.

\section{Dil}

Eserde birden fazla tabakayı temsil eden mektuplar bulunduğundan, dilin yalınlığı ve karmaşıklığı arasında tezatlar bulunur. Farsça ve Arapça kelimeler ile sıkça karşılaşılır. Yazar mektupları toplumun her tabakasındaki insanların ağzından yazar. Alafranga kesimin Fransızca kelimeleri sıkça kullanmasından dolayı çok fazla Fransızca kelime içerir. Bunun yanı sıra Hayat ve Mektuplar adlı eser toplum yararına yönelik yazıldığından dili, bazı mektup parçaları dışında, herkesin anlayabileceği şekilde yalın ve sadedir. Aynı zamanda halkın gündelik konuşma dilinden kelimelere (belkim, sonram, sankim... gibi) ve kasti olarak yapılmış yazım yanlışlarına rastlanır.

Ayrıca bazı mektuplar az kullanılan Arapça kelimeler içerdiği için Latin alfabesine çevrilmekte zorlanılmaktadır. Onun dışında; uzun uzadıya, abartılı cümlelere yer verilmemiş, okuyan her insanın anlayacağı şekilde yazılmıştır. Yazarın eserin dili hakkında eserin ilk sayfalarında verdiği bilgiler şu şekildedir:

"Serâpâ imla ve rabita hatalar ile lafzî ve manevî nakîseler ve şaibelerle âlûde olan ve çirkin bir hat ile yazllan, daha doğrusu, yazdırlan bu saf mektuplarm hemen hepsi bir fabrikanın, selam fabrikasinın malı ve mahsulü gibidir.”(Kestelli, 1925, s. 10)

"Mektuplarda hakikatte mevcut olması lazım gelen imla ve kaide hatalarm bittabi ibka etmedim. Aksi taktirde bu, hiç de hoşa gitmeyecek bir "realizm" olurdu. Eserde, tasvip ettiğim tarz-ı imlâ takip olunmuştu. İşấrât-ı tenkidiyye de keza.. Yalnzz birinci kısım mektuplarda pek tabii ve hakiki olduğu için bazı gülünç terkip ve rabıta hataları bill-iltizâm birakılmıştır. Mektuplar seviye sirasiyla, yani her mektup pek ince bir fark ile mâ-kabline tefevvuk edebilecek bir tarzda tertip ve tasnif edilmiştir. Farazâ on dördüncü mektup yedinci mektuptan, kark sekizince mektup krrk ikinci mektuptan seviye, üslup ve fikir itibarılla herhâlde biraz yüksek bulunacaktır.” (Kestelli, 1925, s. 12)

\section{Sonuç}

Raif Necdet Kestelli döneminin önemli mektup ve eleştiri yazarlarından birisidir. Eserlerini yazdı̆̆ dönemdeki halkın ve vatanın durumunu bütün gerçekleriyle birer fotoğraf karesi edasıyla gözler önüne sermiş, eserin girişinde de belirttiği gibi, eserlerini halkın yararı için yazmıştır. Hayat ve Mektuplar savaş zamanı ve savaş sonrası insanların içinde bulunduğu ekonomik, siyasi, sosyal ve psikolojik durumu ortaya koyan bir eserdir. Geçim sıkıntısı, evlilik kurumu, çocuk sağlığı, eğitim meselesi, okuma-yazma durumu, okulların fizikî yapısı, ticaret, tarım, şehirleşme, sağlık gibi birçok konu ele 
alınarak toplumun krokisi çizilmek istenmiştir. Yazar, eseri roman olarak yazma düşüncesine sahipken bu hedefinden vazgeçmiştir. Dönemin yapısını ve olayları halkın ağzından mektuplar şeklinde anlatarak daha başarılı olacağını düşünmüştür. Çünkü yazarın gayesi, anlatacağı her konuda tarafsız olmak ve halka gerçekçi bir şekilde yansıtabilmektir. Kasıtlı yapılan yazım yanlışları, eserdeki bazı mektuplarda görülen anlatım dilinin zorluğu ve toplumun her kesiminin ağzından mektupları kaleme alınması, yazarın eserde hedefine fazlasıyla yaklaştığının birer kanıtıdır.

Eseri önemli hâle getiren en büyük özellik I. Dünya Savaşı sırasında halkın gözünden anlatılan olayların tarihî bir belge niteliği taşıyabilecek nitelikte olmasıdır.

Yapılan incelemede metin birimlere ayrılmış ve buradan hareketle zihniyeti, yapısı ve dili üzerinde durulmuştur. Böylece hem Cumhuriyet döneminde mektup türünün örneklerinden birine değinilmiş ve bu dönemin özellikleri göz önüne serilmiş hem de Raif Necdet Kestelli’nin yazarlığına, diline ve üslubuna dair bir inceleme yapılmıştır.

\section{Kaynakça}

Aktaş, Ş. (1991). Roman Sanatı ve Roman İncelemesine Giriş. Ankara: Akçağ.

Aydın, R. (2015). Râ'if Necdet ve Yeni Mektub Numuneleri (İnceleme-Metin). Bartın: Bartın Üniversitesi Sosyal Bilimler Enstitüsü Türk Dili ve Edebiyatı ABD, Eski Türk Edebiyatı BD YL Tezi.

Diakova, K., \& Rijova, N. (2013). Обращение В Эпистолярном Жанре (по произведениям русской литературы). Москва: Вестник РУДН.

Donbay, A. (2011). Edebiyatımızda "Mektup" Türü ile İlgili Başlıca Çalışmalar. Erdem Atatürk Kültür Merkezi Dergisi, 83-102.

Eroğlu, E. (2000). Türk Edebiyatında Özel Mektuplar Bibliyografyası. İstanbul: Fatih Üniversitesi Sosyal Bilimler Enstitüsü Türk Dili ve Edebiyatı Anabilim Dalı.

Erol, K. (2017, Kasım 18). Vecize Edebiyatı ve Sosyal Öğreti Örneği Olarak Raif Necdet Kestelli'nin Süzme Sözleri. e-Şarkiyat İlmi Araşttrmalar Dergisi/Journal of Oriental Scientific Research (JOSR), 624643 .

Gökyay, O. Ş. (1974). Tanzimat Dönemine Değin Mektup. Türk Dili Dergisi Mektup Özel Sayısı, 17-23.

Kaplan, E. (1999). Bir Edebî Tür Olarak ektup ve Türk Edebiyatındaki Yeri. Mersin: Mersin Üniversitesi Sosyal Bilimler Enstitüsü Türk Dili ve Edebiyatı Ana Bilim Dalı Yayınlanmamış Yüksek Lisans Tezi.

Karaalioğlu, S. K. (1982). Sözlü-yazıl kompozisyon, konuşmak ve yazmak sanatt. İstanbul: İnkılâp ve Aka.

Karataş, E. (2012). Mektup Roman Tekniği ve Türk Romanından İki Örnek: Mektup Aşkları ve Kedi Mektupları. Turkish Studies, 2173-2192.

Kayabaşı, Ö. (2011). Ahmet Midhat Efendi'nin "Karnaval" Romanını Tahlil Denemesi. Turkish Studies, 659670.

Kestelli, R. N. (1925). Hayat ve Mektuplar. İstanbul: İkdam.

Okay, O. (2010). Batıllaşma Devri Türk Edebiyatı. İstanbul: Dergâh.

Özaktürk, G. (2000). Yazınsal Mektubun Tarihçesi. Ankara: Archivum Anatolicum.

Tekin, M. (2006). Roman Sanatı. İstanbul: Ötüken.

Türk Dil Kurumu;. (2011). Türkçe Sözlük. Ankara: Türk Dil Kurumu.

Ylldırım, Y. (1983/84). Raif Necdet Kestelli'nin Hayatı ve Eserleri. İstanbul: Marmara Üniversitesi, Sosyal Bilimler Enstitüsü Yeni Türk Edebiyatı Ana Bilim Dalı Yüksek Lisans Tezi.

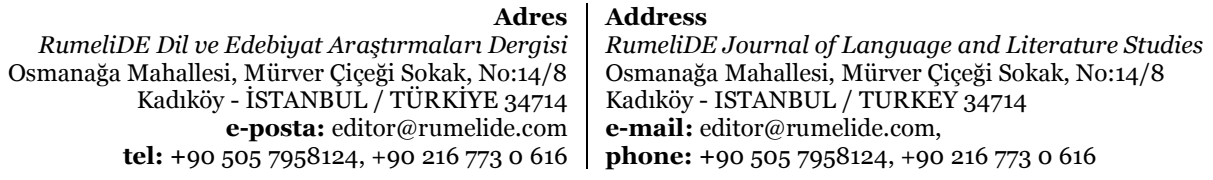

tel: +90 505 7958124, +90 216773 o 616 